\title{
Chemical forms of phosphorous and physicochemical properties of acid soils of Cheha and Dinsho districts, southern highlands of Ethiopia
}

\author{
Bereket Ayenew ${ }^{1 *}$, Abi M. Taddesse ${ }^{2}$, Kibebew Kibret ${ }^{3}$ and Asmare Melese ${ }^{4}$
}

\begin{abstract}
Background: Soil acidity and low availability of $\mathrm{P}$ are among the major problems limiting crop production in the highlands of Ethiopia. The current study was conducted to evaluate the distribution of chemical P forms and selected physical and chemical properties of soils in Cheha and Dinsho districts, southern highlands of Ethiopia. Twelve representative composite soil samples were collected from the surface layer $(0-15 \mathrm{~cm})$ and analyzed for selected soil properties. Analysis of available P and oxalate extractable P, Al and Fe, and P fractionation were done following standard procedures.

Results: The pH of soils in the study area ranged from 4.65 to 5.45 . In the study area the Mehlich-3 extractable $P$ ranged from 8.90 to $25.75 \mathrm{mg} \mathrm{kg}^{-1}$, while the Bray-l extractable $P$ varied from 8.54 to $22.81 \mathrm{mg} \mathrm{kg}^{-1}$. The studied soils had a total $\mathrm{P}$ content that ranged from medium to very high. Mehlich-3 $\mathrm{P}$ was positively and significantly correlated with $\mathrm{pH}, \mathrm{CEC}$ and $\mathrm{OM}$, while it was negatively and significantly $(\mathrm{P} \leq 0.01)$ correlated with exAc and exAl. Oxyhydroxides of iron and aluminum were dominating the exchange sites of the studied soils. In terms of the relative abundance of $\mathrm{P}$ forms, Res-P and $\mathrm{HCl}-\mathrm{P}$ followed by NaOH$-\mathrm{P}_{\mathrm{o}}$ and $\mathrm{NaOH}-\mathrm{P}_{\mathrm{i}}$ were the dominant $\mathrm{P}$ forms in Cheha and Dinsho districts respectively. The total sum of readily available $\mathrm{P}$ forms $\left(\mathrm{NH}_{4} \mathrm{Cl}-\mathrm{P}_{\mathrm{i}}, \mathrm{NaHCO}_{3}-\mathrm{P}_{\mathrm{i}}\right.$ and $\left.\mathrm{NaHCO}_{3}-\mathrm{P}_{0}\right)$ did not exceed $4 \%$ of the total $P$.
\end{abstract}

Conclusion: Soils of the study area were acidic in reaction and found to have low available P. Given the presence of considerable amount of total P, low P availability and high soil acidity in the study areas, further research has to be done on adsorption characteristics to determine the $P$ requirements of the soils for better $P$ management.

Keywords: Amendment, Fractionation, Oxyhydroxide, Phosphate, Acid soils, Ethiopian soils

\section{Background}

Soil acidity and low availability of phosphorous (P) are among the major problems limiting crop production in the highlands of Ethiopia where high rainfall, nutrient leaching, and soil erosion are more prevalent (Asmare et al. 2015). When soil $\mathrm{pH}$ drops below 5, active form of $\mathrm{Al}$ becomes soluble and results in reduced nutrient uptake (Achalu 2014). Reports from numerous

\footnotetext{
*Correspondence: bersofsam12@gmail.com

${ }^{1}$ Department of Chemistry, School of Natural Sciences, Madda Walabu University, Bale-Robe, Ethiopia

Full list of author information is available at the end of the article
}

experiments in P-deficient soils in the highlands of east Africa indicate that the inorganic form of $\mathrm{P}$ assessed by the Olsen method is less than $5 \mathrm{mg} \mathrm{P} \mathrm{kg}{ }^{-1}$ soil (Ikerra 2004). Limited availability of $P$ in many tropical soils can be attributed to severe $\mathrm{P}$ fixation or retention, which is particularly strong in soils with low $\mathrm{P}$ status. In acidic soils, crystalline and non-crystalline oxides of $\mathrm{Fe}$ and $\mathrm{Al}$ (sesquioxides) are the main adsorbing agents of phosphate (Jiang et al. 2015).

Despite the absence of specific system that offers an adequate solution for generalizing or comprehending the behavior of $\mathrm{P}$ in different soils, sequential extraction 
has been used for characterization of complex mixtures that do not lend themselves to conventional chemical analysis (Herlihy and McCarthy 2006). In a review on the use of the Hedley method, contrasting agro-ecosystems of tropical and temperate climates, with different soil use and managements, Negassa and Leinwebe (2009) reported that inorganic and organic fractions of $\mathrm{P}$ could act as a source or sink of available P to plants. The Hedley sequential extraction or fractionation of $\mathrm{P}$ method has also been used to distinguish labile from non-labile fractions and to rank stable fractions and organic fractions in terms of their availability to plants (Cross and Schlesinger 1995). Based on this extraction method, P can be classified as available to plants or microorganisms (labile $\mathrm{P})$, which includes the sum of inorganic $\mathrm{P}(\mathrm{Pi})$ and organic $\mathrm{P}(\mathrm{Po})$ extracted by ammonium chloride $\left(\mathrm{NH}_{4} \mathrm{Cl}\right)$ and sodium bicarbonate $\left(\mathrm{NaHCO}_{3}\right)$. The non-labile $\mathrm{P}$ includes the sum of the remaining fractions ( $\mathrm{Pi}$ and $\mathrm{Po}$ in hydroxide and in sonicate + hydroxide, $\mathrm{Pi}$ in $\mathrm{HCl}$ and residual $\mathrm{P}$ in sulfuric acid digestion). Accurately characterizing $\mathrm{P}$ forms has been proved to overcome the limited information that total $\mathrm{P}$ analysis can provide (Zhou et al. 2001). The quantity of $P$ reserve to replenish solution $P$ and the ability of the soil to maintain sufficient solution $\mathrm{P}$ concentration are the main factors governing P supply to plants (Buresh et al. 1997) and in the absence of fertilization, solution $\mathrm{P}$ is replenished from other soil P pools with different degree of availability.
Even though several works have been done on the relative distribution and forms of P (Duffera and Robarge 1996; Shiferaw 2004; Negassa and Leinwebe 2009; Fisseha et al. 2014; Achalu et al. 2014; Asmare et al. 2015), research related to the different $\mathrm{P}$ forms and distribution encompassing organic $\mathrm{P}$ in the soils of the study areas is scant. Besides, given the role played by phosphorous in agriculture, knowledge on the status of various $\mathrm{P}$ forms, their relative distribution and interaction with other soil attributes that influence $P$ availability in soils of the study area is worth researching. Therefore, this work was initiated to characterize the forms and distributions of $\mathrm{P}$ and their relation with selected soil physical and chemical properties in acidic soils of Dinsho and Cheha districts, southern highlands of Ethiopia.

\section{Methods}

\section{Description of the study area}

The study was conducted in Ethiopian highlands of Dinsho district in Bale zone and Cheha district in Gurage zone, Ethiopia (Fig. 1). Dinsho district lies between $6^{\circ} 58^{\prime} 40^{\prime \prime}$ and $7^{\circ} 20^{\prime} 0^{\prime \prime} \mathrm{N}$, and $39^{\circ} 44^{\prime} 0^{\prime \prime}$ and $40^{\circ} 26^{\prime} 40^{\prime \prime} \mathrm{E}$. Physiographically, most of the land area of the district is situated above $2000 \mathrm{~m}$ above sea level (masl). The district is classified into three agro-climatic zones: highlands (2300-2600 masl), midlands (1500-2300), and lowlands (1200-1500). The district has a bimodal rainfall distribution with mean annual rainfall of about $1150 \mathrm{~mm}$. The

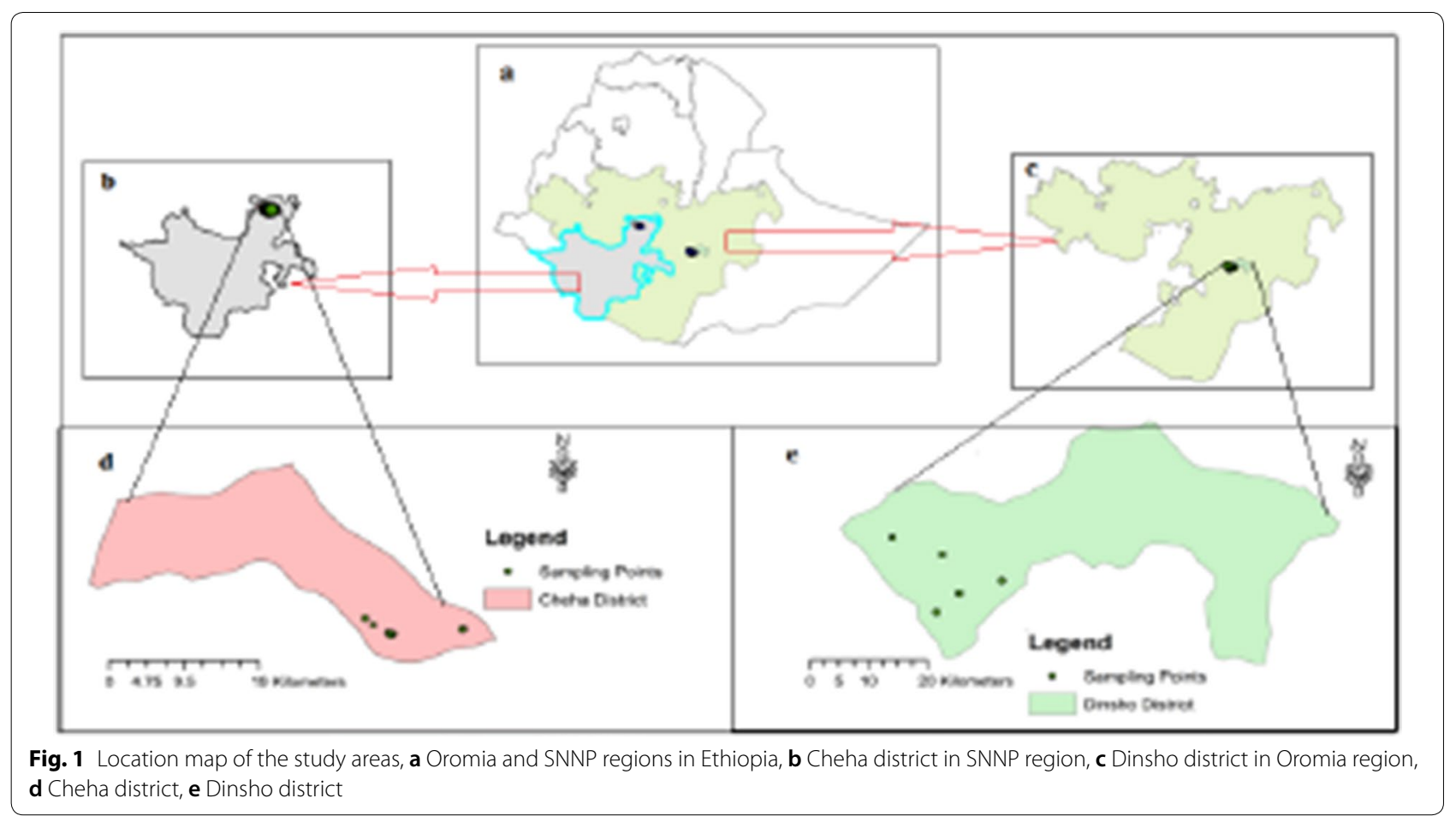


maximum and minimum mean annual temperatures of the District are 17.5 and $6{ }^{\circ} \mathrm{C}$, respectively. Wheat and barley are some of the major cereal crops grown in the area. The major reference soil groups in the district are Pellic Vertisols, Eutric Cambisols, Eutric Nitosols (now Nitisols), and Chromic Luvisols (FAO Food and Agriculture Organization 1984).

Cheha district is situated between $8^{\circ} 32^{\prime} 0^{\prime \prime}$ and $8^{\circ} 20^{\prime} 0^{\prime \prime} \mathrm{N}$, and $37^{\circ} 41^{\prime} 20^{\prime \prime}$ and $38^{\circ} 2^{\prime} 40^{\prime \prime} \mathrm{E}$, at an elevation that ranges from 900 to 2812 masl. EIAR (Ethiopian Institute of Agricultural Research) (2011) classified the area into three agro-ecological zones i.e. highlands (2300-3200 masl), midlands (1500-2300 masl), and lowlands (500-1500 masl) based on the bimodal rain fall system. The 10 years mean annual rainfall of the district is about $1268 \mathrm{~mm}$. The mean annual maximum and minimum temperatures are 24.97 and $10.69{ }^{\circ} \mathrm{C}$, respectively. The dominant soil types are Eutric Nitosols, Leptosols, and Pellic Vertisols (FAO Food and Agriculture Organization 1984).

\section{Site selection, soil sampling, and soil analysis}

A preliminary soil survey and field observation was made using topographic map $(1: 50,000)$ of the study area. Soil $\mathrm{pH}$ (potentiometer), altitude (GPS), and slope (clinometer) were used as criteria for selection of soil sampling sites. Fifteen (15) sub-samples were collected from each sampling site to make one composite sample. Accordingly, twelve composite soil samples $(0-15 \mathrm{~cm})$, seven from Cheha district (Goha 1, Goha 2, Goha 3, Aftir, Abret, Kechot, and Moche), and five from Dinsho district (Doyomarufa 1, Doyomarufa 2, Tulu, Weni, and Ketasire) having $\mathrm{pH}$ values of less than 5.5 were obtained within an altitudinal range of 2000-3000 masl and slope less than $8 \%$ (Table 1). Soil $\mathrm{pH}$ was measured at field condition using portable $\mathrm{pH}$ meter to select soils having a $\mathrm{pH}$ of less than 5.5. The soil samples were put in plastic bag, tagged, and transported to laboratory for analysis during the 2014/2015. Consequently, adequate (about $1 \mathrm{~kg}$ ) amount of composited soil samples were air dried and ground to pass through a $2 \mathrm{~mm}$ sieve for analysis of selected soil chemical and physical properties except organic carbon and total nitrogen in which case the samples were passed through a $0.5 \mathrm{~mm}$ sieve.

\section{Analysis of soil physical and chemical properties}

Soil particle size distribution was analyzed by the Bouyoucos hydrometer method (Day 1965). Soil bulk density was measured from three undisturbed soil samples collected using a core sampler following the procedure described by Jamison et al. (1950). The moisture retention at field capacity (FC) $(-0.33$ bar) and permanent welting point (PWP) ( -15 bar) was determined using the pressure plate apparatus method (Gupta
Table 1 Sampling locations and site description

\begin{tabular}{lllll}
\hline $\begin{array}{l}\text { Sampling } \\
\text { sites }\end{array}$ & $\begin{array}{l}\text { Longitude } \\
(\mathrm{E})\end{array}$ & Latitude (N) & $\begin{array}{l}\text { Altitude } \\
\text { (masl) }\end{array}$ & Slope (\%) \\
\hline SC1 & $037^{\circ} 93^{\prime} 891^{\prime \prime}$ & $08^{\circ} 033^{\prime} 45^{\prime \prime}$ & 2426 & 4 \\
SC2 & $037^{\circ} 94^{\prime} 389^{\prime \prime}$ & $08^{\circ} 032^{\prime} 35^{\prime \prime}$ & 2508 & 3 \\
SC3 & $037^{\circ} 94^{\prime} 134^{\prime \prime}$ & $08^{\circ} 030^{\prime} 78^{\prime \prime}$ & 2498 & 2 \\
SC4 & $037^{\circ} 91^{\prime} 180^{\prime \prime}$ & $08^{\circ} 052^{\prime} 36^{\prime \prime}$ & 2302 & 5 \\
SC5 & $037^{\circ} 92^{\prime} 114^{\prime \prime}$ & $08^{\circ} 043^{\prime} 58^{\prime \prime}$ & 2401 & 3 \\
SC6 & $038^{\circ} 02^{\prime} 572^{\prime \prime}$ & $08^{\circ} 038^{\prime} 63^{\prime \prime}$ & 2603 & 5 \\
SC7 & $038^{\circ} 02^{\prime} 377^{\prime \prime}$ & $08^{\circ} 038^{\prime} 23^{\prime \prime}$ & 2563 & 5 \\
SD1 & $039^{\circ} 51^{\prime} 934^{\prime \prime}$ & $07^{\circ} 075^{\prime} 65^{\prime \prime}$ & 2819 & 4 \\
SD2 & $039^{\circ} 51^{\prime} 900^{\prime \prime}$ & $07^{\circ} 072^{\prime} 28^{\prime \prime}$ & 2832 & 5 \\
SD3 & $039052^{\prime} 387^{\prime \prime}$ & $07^{\circ} 066^{\prime} 39^{\prime \prime}$ & 2790 & 3 \\
SD4 & $039^{\circ} 52^{\prime} 450^{\prime \prime}$ & $07^{\circ} 071^{\prime} 01^{\prime \prime}$ & 2768 & 2 \\
SD5 & $039^{\circ} 52^{\prime} 714^{\prime \prime}$ & $07^{\circ} 080^{\prime} 40^{\prime \prime}$ & 2719 & 5 \\
\hline
\end{tabular}

SC1 Goha 1, SC2 Goha 2, SC3 Goha 3, SC4 Aftir, SC5 Abret, SC6 Kechot, SC7 Moche, SD1 Doyomarufa 1, SD2 Doyomarufa 2, SD3 Tulu, SD4 Weni, SD5 Ketasire

2004). Available water holding capacity (AWHC) was calculated from the difference between moisture content at FC and PWP. Soil $\mathrm{pH}$ measured potentiometrically in $\mathrm{H}_{2} \mathrm{O}$ and $1 \mathrm{M} \mathrm{KCl}$ solution at the ratio of $1: 2.5$ for soil:water and soil: $\mathrm{KCl}$ solutions using a combined glass electrode pH meter (Van Reeuwijk 1992). The soil lime requirement (LR) was determined by Shoemaker, McLean and Pratt (SMP) single buffer procedure (Shoemaker et al. 1961). Cation exchange capacity (CEC) of the soils was determined by making use of the method suggested by Lavkulich (1981). Exchangeable calcium $(\mathrm{Ca})$, magnesium $(\mathrm{Mg})$, potassium $(\mathrm{K})$, and sodium $\mathrm{Na}$ ) were determined by saturating the soil samples with $1 \mathrm{M} \mathrm{NH}_{4} \mathrm{OAc}$ solution at $\mathrm{pH}$ 7.0. Then, $\mathrm{Ca}$ and $\mathrm{Mg}$ were determined by using atomic absorption spectrophotometer (AAS) while exchangeable $\mathrm{Na}$ and $\mathrm{K}$ were measured by flame photometer from the same extract. Exchangeable acidity was determined by saturating the soil samples with $1 \mathrm{M} \mathrm{KCl}$ solution and titrating with $0.02 \mathrm{M} \mathrm{NaOH}$ as described by Rowell (1994).

Total nitrogen was analyzed using the micro-Kjeldahl digestion followed by ammonium distillation and titration method (Bremner 1965). Organic carbon was determined by the dichromate oxidation method as described by Walkley and Black (1934). Available P was determined by different techniques: Bray-I P (by shaking the soil samples with an extracting solution of $0.03 \mathrm{M} \mathrm{NH}_{4} \mathrm{~F}$ in $0.1 \mathrm{M} \mathrm{HCl}$ for $1 \mathrm{~min}$ (Bray and Kurtz 1945) and Mehlich $3 \mathrm{P}$ (by shaking the soil samples with an extracting solution of $0.2 \mathrm{M} \mathrm{CH}_{3} \mathrm{COOH}+0.25 \mathrm{M} \mathrm{NH}_{4} \mathrm{NO}_{3}+0.015 \mathrm{M}$ $\mathrm{NH}_{4} \mathrm{~F}+0.013 \mathrm{M} \mathrm{HNO}_{3}+0.001 \mathrm{M}$ EDTA for $5 \mathrm{~min}$ ) (Mehlich 1984). Total soil $\mathrm{P}$ was determined using the method stated by Olsen and Sommers (1982). 


\section{Soil $\mathrm{P}$ fractionation}

For $\mathrm{P}$ fractionation study, $30 \mathrm{ml}$ of $1 \mathrm{M} \mathrm{NH}_{4} \mathrm{Cl}$ was added in centrifuge tube containing $0.5 \mathrm{~g}$ of soil equilibrated for $16 \mathrm{~h}$ followed by centrifugation, and then the inorganic $\mathrm{P}$ was determined from the extract. To the remaining soil in the tube, $30 \mathrm{ml}$ of $0.5 \mathrm{M} \mathrm{NaHCO}_{3}$ was added and shaken for same period as before, in order to determine inorganic $\mathrm{P}$ and total $\mathrm{P}$ extracted by $\mathrm{NaHCO}_{3}$. The soil in the tube was allowed to interact with $30 \mathrm{ml}$ of $0.1 \mathrm{M} \mathrm{NaOH}$. Then the solution was shaken for $16 \mathrm{~h}$, and centrifuged for determination of inorganic $P$ from the extract. In the fractionation scheme total $\mathrm{P}$ in the $\mathrm{NaOH}$ extract was determined by perchloric acid digestion of the aliquot sample. Subsequently, $30 \mathrm{ml}$ of $0.1 \mathrm{M} \mathrm{NaOH}$ was added into the tube containing the soil and sonicated for $2 \mathrm{~min}$ at $75 \mathrm{~W}$ for the determination of inorganic and total $\mathrm{P}$ in the sonicated $\mathrm{NaOH}$ extract. The remaining soil was treated with $1 \mathrm{M} \mathrm{HCl}$ followed by shaking and centrifugation of the soil containing $30 \mathrm{ml}$ of $1 \mathrm{~N} \mathrm{HCl}$ in order to determine the inorganic $\mathrm{P}$ in the $\mathrm{HCl}$ extract. Finally, the soil was digested with a mixture of concentrated $\mathrm{HNO}_{3}$ and $\mathrm{HClO}_{4}$ acids in order to determine the residual $\mathrm{P}$. Accordingly, the $\mathrm{P}$ fractions were successively extracted with $1 \mathrm{M} \mathrm{NH}_{4} \mathrm{Cl}$ (available Pi), $0.5 \mathrm{NaHCO}_{3}$ (labile Pi and Po adsorbed on the soil surface), $0.1 \mathrm{M} \mathrm{NaOH}$ (moderately labile Pi and Po held more strongly by Chemisorption to surfaces of $\mathrm{Al}$ and $\mathrm{Fe}$ oxides), Sonicate $+0.1 \mathrm{M}$ $\mathrm{NaOH}$ (Pi and Po adsorbed within surfaces of $\mathrm{Al}$ and $\mathrm{Fe}$ oxides of soil aggregates-occluded $\mathrm{P}), 1 \mathrm{M} \mathrm{HCl}$ (P associated to $\mathrm{Ca}$, derived from primary mineral-apatite) and a mixture of $\mathrm{HNO}_{3}$ and $\mathrm{HClO}_{4}$ (residual P-non-labile, stable Po forms and relatively insoluble $\mathrm{Pi}$ forms) as described by Hedley et al. (1982) and modified by Chen et al. (2000).

The oxalate extractable $\mathrm{P}, \mathrm{Al}$ and $\mathrm{Fe}\left(\mathrm{P}_{\mathrm{ox}}, \mathrm{Al}_{\mathrm{ox}}\right.$ and $\mathrm{Fe}_{\text {ox }}$ ) were determined with $0.05 \mathrm{M}$ ammonium oxalate $\left[\left(\mathrm{NH}_{4}\right)_{2} \mathrm{C}_{2} \mathrm{O}_{4} \cdot 2 \mathrm{H}_{2} \mathrm{O}, \mathrm{pH} 3.3\right]$ in the dark (Mckeague and Day 1966). Citrate bicarbonate dithionite-extractable $\mathrm{Fe}$ and $\mathrm{Al}\left(\mathrm{Fe}_{\mathrm{d}}\right.$ and $\left.\mathrm{Al}_{\mathrm{d}}\right)$ were determined by the method of Mehra and Jackson (1960). Degree of P saturation was determined from total phosphorous sorption capacity $\left(\mathrm{PSC}_{\mathrm{t}}\right)$ which is alienated into $\mathrm{P}$ occupied sites and remaining $\mathrm{P}$ sorption capacity $\left(\mathrm{PSC}_{\mathrm{r}}\right)$. The amount of $\mathrm{P}$ sorbed on the $\mathrm{PSC}_{t}$ was evaluated from $\mathrm{PSC}_{\mathrm{r}}$ and oxalateextractable $\mathrm{P}\left(\mathrm{P}_{\mathrm{ox}}\right)$. Likewise, the $\mathrm{PSC}_{\mathrm{r}}$ was calculated by multiplying an experimental $P$ sorption capacity $\left(F_{r}\right)$ by a factor of 2.75 (Maguire et al. 2001). Experimental P sorption capacity was determined by the standardized onepoint short-term isotherm method (Bache and Williams 1971). Three gram of $2 \mathrm{~mm}$ soil was shaken with $60 \mathrm{ml}$ of a $75 \mathrm{mg} \mathrm{P} \mathrm{l}^{-1}$ as $\mathrm{KH}_{2} \mathrm{PO}_{4}$ equivalent to $1.5 \mathrm{~g} \mathrm{P} \mathrm{kg}^{-1}$ soil in $0.01 \mathrm{M} \mathrm{CaCl}_{2}$ solution for $18 \mathrm{~h}$ with some drops of chloroform. The sorbed $\mathrm{P}\left(\mathrm{F}_{\mathrm{r}}\right)$ was calculated as the difference between added $\mathrm{P}$ and $\mathrm{P}$ remaining in solution. Accordingly, the degree of $\mathrm{P}$ saturation (DPS) was determined as the percentage of the ratio of the different forms of $\mathrm{P}$ to the oxalate extractable $\mathrm{Al}$ and $\mathrm{Fe}\left(\mathrm{Al}_{\mathrm{ox}}\right.$ and $\left.\mathrm{Fe} \mathrm{ox}\right)$ as follows (Van der Zee et al. 1988):

DPS as the percentage of ratio of $P_{\text {ox }}$ to PSC

$$
\text { DPS } \mathrm{P}_{\mathrm{ox}}=\left(\mathrm{P}_{\mathrm{ox}} / \mathrm{PSC}\right) \times 100
$$

The $\mathrm{P}$ adsorption capacity (PSC, $\mathrm{mmol} \mathrm{kg}{ }^{-1}$ ) of the soil was calculated and estimated by (Börling et al. 2001):

$$
\mathrm{PSC}=\alpha\left(\mathrm{Al}_{\mathrm{ox}}+\mathrm{Fe}_{\mathrm{ox}}\right)
$$

where $\mathrm{Al}_{\text {ox }}$ and $\mathrm{Fe}_{\text {ox }}$ are oxalate-extractable $\mathrm{Al}$ and $\mathrm{Fe}$, and $\alpha$ is a scaling factor.

The $\alpha$ scale factor was estimated by:

$$
\begin{aligned}
& \mathrm{PSC}_{\mathrm{t}}=\mathrm{PSC}_{\mathrm{r}}+\mathrm{P}_{\mathrm{ox}} \\
& \mathrm{PSC}_{\mathrm{r}}=\mathrm{F}_{\mathrm{r}} * 2.75 \\
& \alpha=\frac{P_{o x}+P S C_{r}}{F e_{o x}+A l_{o x}}
\end{aligned}
$$

The $\mathrm{F}_{\mathrm{r}}, \mathrm{PSC}_{\mathrm{r}}, \mathrm{PSC}_{\mathrm{t}}$ parameters and $\alpha$ scale factor were determined for the twelve soil samples and the mean $\alpha$ was used to calculate PSC and DPS.

\section{Statistical analysis}

Pearson's simple correlation coefficient was executed using Statistical Analysis System (SAS) version 9.1 (SAS (Statistical Analysis System) version 9.1. SAS Institute 2004) to evaluate the magnitudes and directions of relationship between the different $\mathrm{P}$ forms and other related soil properties.

\section{Results and discussion \\ Characteristics of selected soil physical properties}

The selected soil physical properties of the studied soils are indicated in Table 2. The textural class of the studied soils is predominantly clay. Generally, the clay content of the studied soils ranged from 36.6 to $49.8 \%$ and the highest clay content was recorded from SC3 soil and the lowest was obtained from SD3 soil. This difference in clay content could be attributed to the variability in the degree of weathering of the soils. The bulk density values ranged from 1.11 to $1.32 \mathrm{~g} \mathrm{~cm}^{-3}$ with a mean value of $1.21 \mathrm{~g} \mathrm{~cm}^{-3}$ and the bulk density values of the studied soils were found to be within the normal range suggested for clay soils, which ranges from 1.0 to $1.6 \mathrm{~g} \mathrm{~cm}^{-3}$ (Aubertin and Kardos 1965). The observed variability in bulk density among the studied soils might be due to differences in organic matter content of the soils. Moreover, potential root restriction of the soils is 
Table 2 Selected physical properties of the soils studied

\begin{tabular}{|c|c|c|c|c|c|c|c|c|}
\hline \multirow[t]{2}{*}{ Sampling sites } & \multicolumn{3}{|c|}{ Particle size distribution (\%) } & \multirow[t]{2}{*}{ Textural class } & \multirow{2}{*}{$\begin{array}{l}\text { Bulk density } \\
\left(\mathrm{g} \mathrm{cm}^{3}\right)\end{array}$} & \multicolumn{2}{|c|}{ Water content at (\%) } & \multirow[t]{2}{*}{ AWHC (\%) } \\
\hline & Sand & Silt & Clay & & & FC & PWP & \\
\hline SC1 & 23.2 & 28.6 & 48.2 & Clay & 1.32 & 31.00 & 19.60 & 11.40 \\
\hline SC2 & 22.8 & 32.6 & 44.6 & Clay & 1.25 & 32.25 & 22.25 & 10.00 \\
\hline SC3 & 23.2 & 27.0 & 49.8 & Clay & 1.29 & 31.00 & 20.55 & 9.65 \\
\hline SC4 & 19.4 & 34.0 & 46.6 & Clay & 1.22 & 31.95 & 21.75 & 10.20 \\
\hline SC5 & 14.8 & 37.2 & 48.0 & Clay & 1.21 & 31.65 & 20.90 & 10.75 \\
\hline SC6 & 19.6 & 37.0 & 43.4 & Clay & 1.24 & 32.90 & 22.50 & 10.40 \\
\hline SC7 & 22.0 & 33.0 & 45.0 & Clay & 1.24 & 32.70 & 21.80 & 10.90 \\
\hline SD1 & 29.6 & 32.6 & 37.8 & Clay & 1.13 & 31.60 & 21.60 & 10.00 \\
\hline SD2 & 23.8 & 32.6 & 43.6 & Clay & 1.16 & 33.00 & 22.70 & 10.30 \\
\hline SD3 & 29.0 & 34.4 & 36.6 & Clay loam & 1.11 & 39.15 & 22.20 & 16.95 \\
\hline SD4 & 26.8 & 29.0 & 44.2 & Clay & 1.17 & 38.10 & 25.11 & 12.99 \\
\hline SD5 & 29.2 & 32.6 & 38.2 & Clay loam & 1.16 & 32.31 & 20.72 & 11.59 \\
\hline
\end{tabular}

SC1 Goha 1, SC2 Goha 2, SC3 Goha 3, SC4 Aftir, SC5 Abret, SC6 Kechot, SC7 Moche, SD1 Doyomarufa 1, SD2 Doyomarufa 2, SD3 Tulu, SD4 Weni, SD5 Ketasire

presumed to be less as the bulk densities are less than $1.4 \mathrm{~g} \mathrm{~cm}^{-3}$ (Hazelton and Murphy 2007). The soil water content at FC ranged from 30.2 to $39.2 \%$ with mean value of $33.1 \%$. According to the result obtained from FC and PWP measurements, soil samples collected from Dinsho district showed relatively higher water retention compared with soil samples collected from Cheha. This difference could be attributed to the relatively higher organic matter content of the former. The PWP and AWHC ranged from 19.6 to 25.1 and 9.7 to $16.9 \%$ with mean values of 21.8 and $11.3 \%$, respectively.

\section{Soil $\mathrm{pH}$, buffer $\mathrm{pH}$ and lime requirements}

The $\mathrm{pH}\left(\mathrm{H}_{2} \mathrm{O}\right)$ values of the soils varied between 4.65 and 5.45 (Table 3 ). Based on the rating suggested by Jones (2003), $58 \%$ of the sampled soils were found to be very strongly acidic while $42 \%$ could be considered as strongly acidic. The $\mathrm{pH}(\mathrm{KCl})$ values of the studied soils varied from 3.98 to 4.46 . The $\mathrm{pH}$ measured in potassium chloride solution was lower than $\mathrm{pH}$ measured in water for all the soil samples. The greater amount of exchangeable $\mathrm{Al}\left(0.21-1.54 \mathrm{cmol}_{\mathrm{c}} \mathrm{kg}^{-1}\right)$ at the exchange sites might have contributed for the lower $\mathrm{pH}(\mathrm{KCl})$ value in solution of the studied soils. The finding of the present

Table 3 Soil pH, buffer $\mathrm{pH}$ and lime requirements

\begin{tabular}{|c|c|c|c|c|c|c|}
\hline \multirow[t]{2}{*}{ Sampling sites } & \multicolumn{3}{|l|}{$\mathrm{pH}$} & \multirow{2}{*}{$\begin{array}{l}\Delta \mathrm{pH} \\
\mathrm{KCl}\end{array}$} & \multicolumn{2}{|c|}{$\mathrm{LR}$ (tons $\mathrm{CaCO}_{3} \mathrm{ha}^{-1}$ ) } \\
\hline & $\mathrm{H}_{2} \mathrm{O}$ & $\mathrm{KCl}$ & Buffer & & $\mathrm{pH}(6.0)$ & $\mathrm{pH}(6.5$ \\
\hline $\mathrm{SC}_{1}$ & 4.65 & 3.98 & 5.11 & 0.66 & 9.20 & 11.50 \\
\hline $\mathrm{SC} 2$ & 4.79 & 4.05 & 5.41 & 0.74 & 7.80 & 9.60 \\
\hline $\mathrm{SC} 3$ & 4.73 & 4.04 & 5.20 & 0.68 & 8.70 & 10.70 \\
\hline $\mathrm{SC} 4$ & 4.81 & 4.10 & 5.31 & 0.71 & 8.20 & 10.00 \\
\hline SC5 & 5.13 & 4.22 & 5.61 & 0.90 & 6.70 & 8.20 \\
\hline SC6 & 4.76 & 4.12 & 5.30 & 0.64 & 8.20 & 10.00 \\
\hline $\mathrm{SC} 7$ & 4.91 & 4.09 & 5.31 & 0.82 & 8.20 & 10.00 \\
\hline SD1 & 5.30 & 4.38 & 6.20 & 0.92 & 3.70 & 4.60 \\
\hline SD2 & 5.01 & 4.21 & 6.11 & 0.79 & 4.10 & 5.00 \\
\hline SD3 & 5.12 & 4.29 & 6.51 & 0.83 & 2.10 & 2.60 \\
\hline SD4 & 5.36 & 4.42 & 6.31 & 0.94 & 3.30 & 4.00 \\
\hline SD5 & 5.45 & 4.46 & 6.41 & 0.99 & 2.80 & 3.40 \\
\hline Mean & 5.00 & 4.20 & 5.73 & 0.79 & 6.08 & 7.47 \\
\hline
\end{tabular}

LR lime requirements, SC1 Goha 1, SC2 Goha 2, SC3 Goha 3, SC4 Aftir, SC5 Abret, SC6 Kechot, SC7 Moche, SD1 Doyomarufa 1, SD2 Doyomarufa 2, SD3 Tulu, SD4 Weni, SD5 Ketasire 
study concurs with previous reports which described that the $\mathrm{pH}$ measured in chloride solution is lower than $\mathrm{pH}$ measured in water because of the larger amount of $\mathrm{H}^{+}$ ion forced to soil solution when $\mathrm{Al}^{3+}$ or $\mathrm{Fe}^{3+}$ are replaced by $\mathrm{K}^{+}$on the exchange sites (Kissel and Vendrell PF Isaac 2004; Asmare et al. 2015). According to USDANRCS (2004) report, the numerical difference in the values of $\mathrm{pH}$ measured in $\mathrm{KCl}$ and $\mathrm{H}_{2} \mathrm{O}$ is referred to as the delta $\mathrm{pH}(\Delta \mathrm{pH})$. When this difference is negative, the colloid has a net negative charge, and when positive, it has a net positive charge. The $\Delta \mathrm{pH}$ value obtained for the studied soil samples indicates that the colloid has a net positive charge. The highest difference between $\mathrm{pH}-\mathrm{H}_{2} \mathrm{O}$ and $\mathrm{pH}$ $\mathrm{KCl}$ was found for soil sample SD5 from Dinsho (0.99 $\mathrm{pH}$ units) and the lowest ( $0.66 \mathrm{pH}$ units) was for the soil sample SC1 from Cheha district. The variation in abundance of exchangeable $\mathrm{Al}$ which ranged from 0.21 to 1.54 $\mathrm{cmol}_{\mathrm{c}} \mathrm{kg}^{-1}$ might be a possible rationale for the disparity of $\Delta \mathrm{pH}$ among soils of the study area.

The hydrogen ion $\left(\mathrm{H}^{+}\right)$concentration that exists on the soil colloids (buffer $\mathrm{pH}$ ) was evaluated for soil samples and varied between 5.11 and $6.51 \mathrm{pH}$ units. The LR values, as determined by the SMP single buffer method to raise the $\mathrm{pH}$ of the soils to target $\mathrm{pH}$ values of 6.0 and 6.5 are presented in Table 3. Consequently, the amount of lime required to raise the respective $\mathrm{pH}$ values of the studied soils to the target $\mathrm{pH}$ of 6.0 and 6.5 ranged from 2.10 to $9.20 \mathrm{t} \mathrm{CaCO}_{3} \mathrm{ha}^{-1}$ and $2.60-11.50 \mathrm{t} \mathrm{CaCO}_{3}$ $\mathrm{ha}^{-1}$ respectively. Therefore, the soils of the study area need substantial amount of lime to alleviate the acidity problem and increase the productivity of acid sensitive crops. Likewise, the output of the correlation matrix in
Table 8 shows a strong significant and negative correlation between $\mathrm{pH}$ and $\mathrm{LR}(\mathrm{r}=-0.88, \mathrm{P} \leq 0.01)$. Hence, the lower the $\mathrm{pH}$ value of the soil, the higher is the amount of liming material needed to increase the $\mathrm{pH}$ to a suitable range for sustainable production of acid sensitive crops.

\section{Exchangeable cations and exchange properties}

The cation exchange capacity of soils of Cheha district (SC1-SC5) showed a relatively lower range (21.15-31.54 $\mathrm{cmol}_{\mathrm{c}} \mathrm{kg}^{-1}$ ) than soils from Dinsho district (SD1-SD5) (31.14-36.03 $\mathrm{cmol}_{\mathrm{c}} \mathrm{kg}^{-1}$ ) (Table 4). According to Hazelton and Murphy (2007) the CEC of the soils were in the range of moderate to high values. The variation in CEC among the soils might be due to the difference in $\mathrm{OM}$ content, clay mineralogy between some soil forms and the $\mathrm{pH}$ range in which the soils exist. In agreement with the current study, Peinemann et al. (2000) declared that clay and organic matter are the main sources of CEC and the more clay and organic matter (humus) a soil contains, the higher is its CEC.

As per the ratings suggested by Hazelton and Murphy (2007), the exchangeable $\mathrm{Na}$ was in the range of very low to moderate in the study area. Whereas the exchangeable $\mathrm{Ca}$ and $\mathrm{Mg}$ were in the range of low to moderate for soils from Cheha and moderate to high for Dinsho district. In Cheha district, the variation in concentration levels of exchangeable $\mathrm{K}$ among the soils followed the same trend with that of $\mathrm{Ca}$ and $\mathrm{Mg}$ whereas it was moderate in Dinsho district. Barber (1984) indicated that the critical level of exchangeable $\mathrm{K}$ for optimum crop production is 0.38 $\mathrm{cmol}_{\mathrm{c}} \mathrm{kg}^{-1}$. The status of exchangeable bases in soil from Dinsho was slightly higher than soils from Cheha. The

Table 4 Exchangeable cations and exchange properties

\begin{tabular}{|c|c|c|c|c|c|c|c|c|c|c|c|c|c|}
\hline \multirow[t]{2}{*}{ Soil } & \multicolumn{9}{|c|}{ Exchangeable cations and CEC $\left(\mathrm{cmol}_{\mathrm{c}} \mathrm{kg}^{-1}\right)$} & \multicolumn{3}{|c|}{ Percent saturation (\%) } & \multirow{2}{*}{$\begin{array}{l}\mathrm{K} / \mathrm{Mg} \\
\text { Ratio }\end{array}$} \\
\hline & $\mathrm{Ca}$ & Mg & K & $\mathrm{Na}$ & TEB & exAc & exAl & CEC & ECEC & PAcS & PAIS & PBS & \\
\hline SC1 & 4.21 & 0.98 & 0.20 & 0.04 & 5.43 & 2.61 & 1.54 & 19.15 & 10.56 & 13.63 & 8.04 & 28.36 & 0.20 \\
\hline SC2 & 8.45 & 2.23 & 0.26 & 0.09 & 11.03 & 2.18 & 0.82 & 23.88 & 17.77 & 9.13 & 3.43 & 46.19 & 0.12 \\
\hline SC3 & 4.91 & 1.11 & 0.25 & 0.09 & 6.36 & 2.38 & 1.29 & 20.88 & 11.12 & 11.40 & 6.18 & 30.46 & 0.23 \\
\hline SC4 & 7.86 & 1.69 & 0.28 & 0.11 & 9.96 & 1.57 & 0.35 & 26.98 & 14.09 & 5.82 & 1.30 & 36.92 & 0.17 \\
\hline SC5 & 8.95 & 2.38 & 0.30 & 0.11 & 11.74 & 1.09 & 0.42 & 22.81 & 15.39 & 4.78 & 1.84 & 51.47 & 0.13 \\
\hline SC6 & 6.40 & 1.42 & 0.29 & 0.12 & 8.25 & 2.11 & 0.43 & 29.54 & 12.93 & 7.14 & 1.46 & 27.93 & 0.20 \\
\hline SC7 & 9.42 & 2.05 & 0.32 & 0.16 & 11.92 & 2.29 & 0.49 & 25.03 & 16.77 & 9.15 & 1.96 & 47.62 & 0.16 \\
\hline SD1 & 13.30 & 2.87 & 0.34 & 0.25 & 16.76 & 0.59 & 0.28 & 33.70 & 18.73 & 1.75 & 0.83 & 49.73 & 0.12 \\
\hline SD2 & 9.29 & 2.14 & 0.32 & 0.21 & 11.97 & 0.87 & 0.32 & 29.80 & 14.44 & 2.92 & 1.07 & 40.17 & 0.15 \\
\hline SD3 & 14.78 & 4.39 & 0.41 & 0.38 & 19.96 & 0.62 & 0.24 & 34.03 & 25.95 & 1.82 & 0.71 & 58.65 & 0.09 \\
\hline SD4 & 10.87 & 3.52 & 0.34 & 0.20 & 14.93 & 0.56 & 0.22 & 29.14 & 17.87 & 1.92 & 0.75 & 51.24 & 0.10 \\
\hline SD5 & 12.90 & 3.77 & 0.37 & 0.23 & 17.27 & 0.59 & 0.21 & 30.66 & 21.25 & 1.92 & 0.68 & 56.33 & 0.10 \\
\hline Mean & 9.28 & 2.38 & 0.31 & 0.17 & 12.13 & 1.46 & 0.55 & 27.13 & 16.41 & 5.95 & 2.35 & 43.75 & 0.13 \\
\hline
\end{tabular}

$T E B$ total exchangeable bases, exAc exchangeable acidity, exAl exchangeable Aluminum, CEC cation exchange capacity of soil, ECEC Effective cation exchange capacity, $P A C S$ percent acid saturation, $P A I S$ percent aluminium saturation, $P B S$ percent base saturation 
likely reason for the observed variation in exchangeable bases could be the difference in soil $\mathrm{pH}$ and organic carbon content. It has been reported that soil $\mathrm{pH}$ and soil $\mathrm{OC}$ are regarded as the main factors influencing the variation in exchangeable cations (YuGe et al. 2013). Based on this critical level, except soil from SD3 the entire soil samples from both districts had an exchangeable $\mathrm{K}$ concentration of below the optimum level. Other study results have also reported about the insufficiency of $\mathrm{K}$ in acidic soils of Ethiopia (Mesfin et al. 2014; Asmare et al. 2015). The persuasive reason for the scarcity of exchangeable $\mathrm{K}$ could be attributed to the higher intensity of weathering and intensive cultivation.

The distributions of these basic cations in the exchange complex followed the order of $\mathrm{Ca}^{2+}>\mathrm{Mg}^{2+}>\mathrm{K}^{+}>\mathrm{Na}^{+}$. The variations in the order of distribution of these cations could be related to the charge density in which the divalent cations $\left(\mathrm{Ca}^{2+}\right.$ and $\left.\mathrm{Mg}^{2+}\right)$ have higher affinity towards the colloidal surface than monovalent ions $\left(\mathrm{K}^{+}\right.$ and $\mathrm{Na}^{+}$) (Alemu et al. 2016). Similar order of distribution of these cations was reported by several studies (Teshome et al. 2013; Asmare et al. 2015; Okubay et al. 2015). Antagonistic effects are known to exist between $\mathrm{Mg}$ and K (FAO 2006) when disproportionate quantities of the cations are present in soil. In this study, the ratio was evaluated and ranged from 0.09 to 0.23 (Table 4). According to the recommendation noted by Abayneh and Ashenafi (2006), potassium is deficient for field crops (5:1), vegetables (3:1) and fruits (2:1) in soils from Dinsho and Cheha districts. On the other hand, according to the ratio $(0.7: 1)$ suggested by Loide (2004), the clay textured soils of the study area showed $\mathrm{Mg}$ induced $\mathrm{K}$ deficiency. The observed order $\left(\mathrm{Ca}^{2+}>\mathrm{Mg}^{2+}>\mathrm{K}^{+}>\mathrm{Na}^{+}\right)$of cations concentration in the exchange complex could also substantiate the existence of $\mathrm{Mg}$ induced $\mathrm{K}$ deficiency.

The percentage base saturation (PBS) of the studied soils varied from 25.66 to $55.39 \%$ (Table 4). Based on the rating suggested by Hazelton and Murphy (2007), about $50 \%$ of the soils had a PBS value that is within the range of low (25.66-34.35\%) to moderate (42.64-47.3\%).The possible reason for the low PBS value of soils might be the loss of soluble basic cations through leaching and erosion. Research results made on other Ethioipian soils also revealed low values of PBS in acidic soils possibly due to intensive cultivation, enhanced loss of basic cations through leaching and erosion (Getachew and Heluf 2007; Mohhammed et al. 2016).

The exchangeable acidity (exAc) and exchangeable aluminium (exAl) of the studied soils were found to be in the range of $0.56-2.61$ and $0.21-1.54 \mathrm{cmol}_{\mathrm{c}} \mathrm{kg}^{-1}$, respectively (Table 4). Meanwhile, the acid saturation (PAcs) and $\mathrm{Al}$ saturation (PAls) ranged from 1.75 to 13.63 and 0.68 to $8.04 \%$, respectively. Variability was observed among soils of the two districts in terms of exAc and exAl. The disparity in these values between the two locations might be due to the difference in soil CEC. In agreement with the present study, Al Baquy et al. (2017) attributed the difference in exAc and exAl to the difference in soil type, organic matter content and CEC of soils.

The correlation result in Table 8 shows that exAc and exAl were negatively correlated with $\mathrm{pH}$, whereas significant positive correlation was observed between $\mathrm{pH}$ and extractable $\mathrm{P}$ (Mehlich 3-P). This indicates that the lower the $\mathrm{pH}$ of the soil, the higher will be the concentrations of exAl and exAc. Strong and positive correlation was also observed between LR of soils and exAl $(r=0.71$, $\mathrm{P} \leq 0.01)$ and exAc $(\mathrm{r}=0.94, \mathrm{P} \leq 0.01)$. The result of this correlation study is concomitant with what was reported by Asmare et al. (2015) and indicates that higher dose of lime is required for soils with higher exchangeable $\mathrm{Al}$ and acidity. Therefore, $\mathrm{pH}$, amount of exchangeable acidity and $\mathrm{Al}$ can provide preliminary information on LR of soils. Cation exchange capacity (CEC) was negatively correlated with exAc and exAl $[\mathrm{r}=-0.78, \mathrm{P} \leq 0.01$ and $\mathrm{r}=-0.83, \mathrm{P} \leq 0.01]$. This correlation indicates that soils with high exAc and exAl have lower CEC. This could be an indication of weaker desorption of $\mathrm{P}$ associated with oxyhydroxides of $\mathrm{Fe}$ and $\mathrm{Al}$ for soils having higher exchangeable $\mathrm{Al}$ and exchangeable acidity. Furthermore, the strong negative correlation between CEC of soil and clay content $[\mathrm{r}=-0.67, \mathrm{P} \leq 0.05]$ reveals that the difference in CEC can be explained by the difference in clay contents among some soils (De Kimpe et al. 1979).

\section{Organic carbon, total nitrogen, available and total phosphorus}

As the result of soil analysis for $\mathrm{OC}$, total $\mathrm{N}, \mathrm{C}: \mathrm{N}$ ratio, available and total $\mathrm{P}$ contents of the studied soils illustrated the percentage of organic carbon and total nitrogen in the soils of Cheha district varied from 1.58 to 2.11 and $0.17-0.19 \%$, respectively and were appeared to be higher values compared to soils of Dinsho district (2.152.58 and $0.19-0.22 \%$ respectively) (Table 5 ). In general, as per the rating suggested by Hazelton and Murphy (2007), OC content of soils of the study area were within the range of moderate (1.00-1.80\%) to high (1.80-3.00\%). Even though soils of the study area have been intensively tilled, the crop residue that is often left after crop harvest, a common practice in the study area, might have contributed to this level of organic carbon in the soils. Furthermore, high clay content, which controls organic matter enrichment ability of soils, could also be another reason for the moderate to high organic carbon content in soils of the study area. The variation in percent clay fraction, management practices and intensity of cultivation might have contributed for the slight disparity in OC matter 
Table 5 Organic carbon (OC), total nitrogen (TN), available and total phosphorus $(P)$ OC $=$ organic carbon, $T N=$ total nitrogen, $\mathrm{C}: \mathrm{N}=$ carbon to nitrogen ratio

\begin{tabular}{|c|c|c|c|c|c|c|}
\hline Sampling sites & $\begin{array}{l}\text { OC } \\
(\%)\end{array}$ & TN & C:N & $\begin{array}{l}\text { Mehlich } 3 \text { P } \\
\left(\mathrm{mg} \mathrm{kg}^{-1}\right)\end{array}$ & Bray $1 \mathrm{P}$ & Total P \\
\hline $\mathrm{SC} 1$ & 1.58 & 0.17 & 9.55 & 8.90 & 8.54 & 648.62 \\
\hline $\mathrm{SC} 2$ & 1.86 & 0.17 & 11.24 & 10.14 & 9.65 & 806.55 \\
\hline $\mathrm{SC} 3$ & 1.93 & 0.19 & 9.89 & 9.73 & 8.95 & 708.11 \\
\hline SC4 & 1.97 & 0.18 & 11.23 & 9.15 & 7.78 & 728.20 \\
\hline SC5 & 2.11 & 0.19 & 11.38 & 10.79 & 7.61 & 693.18 \\
\hline SC6 & 2.00 & 0.18 & 11.43 & 13.94 & 7.90 & 789.43 \\
\hline SC7 & 1.91 & 0.19 & 10.32 & 10.38 & 7.61 & 736.77 \\
\hline SD1 & 2.39 & 0.19 & 12.89 & 23.26 & 19.36 & 1094.25 \\
\hline SD2 & 2.37 & 0.20 & 11.85 & 18.33 & 16.15 & 1022.80 \\
\hline SD3 & 2.58 & 0.22 & 11.98 & 24.35 & 21.41 & 1175.80 \\
\hline SD4 & 2.56 & 0.21 & 12.17 & 22.29 & 20.24 & 1045.60 \\
\hline SD5 & 2.52 & 0.21 & 12.29 & 21.34 & 20.12 & 1130.15 \\
\hline Mean & 2.15 & 0.19 & 11.35 & 14.84 & 12.59 & 881.62 \\
\hline
\end{tabular}

SC1 Goha 1, SC2 Goha 2, SC3 Goha 3, SC4 Aftir, SC5 Abret, SC6 Kechot, SC7 Moche, SD1 Doyomarufa 1, SD2 Doyomarufa 2, SD3 Tulu, SD4 Weni, SD5 Ketasire

content of the soils. Many studies confirm that carbon retention in soil is influenced by crop management systems, such as crop rotation (Saljnikov et al. 2004), tillage (Saljnikov et al. 2009), residue management (Rasmussen et al. 1980) and fertilization and fertility (Saljnikov et al. 2005).

In addition to the above-mentioned reasons, the high silt plus clay content of the soils might have contributed to the moderate to high organic carbon content. Numerous studies have described the positive relationship between clay (or clay + silt) content and soil organic matter $(\mathrm{OM})$ in soils from different sites in the tropics (Xiea and Steinbergera 2001). These studies have shown that clay-silt content is a relatively important determinant of soil OM or total OC level in soils. As a case in point, studies in Spanish semi-arid Mediterranean bare soils have shown different soil OM mineralization rates for different soil textures (Garcõ̂Aa and HernaÂndez 1996) and indicated the importance of the physical and chemical properties, which might have played an important role in soil water availability. It has also been suggested that fine particles with high surface activity may physically and chemically protect soil OM from decomposition by binding strongly and create physical barrier to protect microbial access (Hassink et al. 1993).

As per the rating suggested by Hazelton and Murphy (2007), the total nitrogen (TN) content of soils in the study area was within the range of medium (0.17$0.22 \%$ ). However, medium TN level in soils of the study area could not be taken as a guaranty for adequate availability of $\mathrm{N}$ to plants. Therefore, in order to maintain or enhance the nitrogen status of the soils imbalanced use of fertilizers, nutrient mining through intensive cultivation and crop residue removal should be avoided. The slight variation within sites in particular might be associated to the variability of soils OC content.

The C:N ratio of the studied soils varied between 9.54 and 12.89. According to the recommendation made by Newey (2006), 17 and $83 \%$ of the studied soils were categorized under soils having very low $(<10)$ and low (10-15) C:N ratio respectively indicating the fast decomposition of OM in the studied soils. Abera and Belachew (2011) investigated soils from cultivated lands of Bale Zone including Dinsho and reported a C:N ratio ranging from 12.57 to 13.53 , which is comparable with the findings of the current study.

Total $\mathrm{P}$ content in the surface soil samples ranged from $648.62 \mathrm{mg} \mathrm{kg}^{-1}$ in the SC1 soil collected from Cheha farmers' field to $1175.8 \mathrm{mg} \mathrm{kg}^{-1}$ in the SD3 soil collected from the Dinsho district (Table 5).

The amount of $\mathrm{P}$ extracted with Mehlich-3 and Bray and Kurtz-1 ranged from 8.90 to 25.75 and 8.54 to $22.81 \mathrm{mg} \mathrm{kg}^{-1}$ respectively (Table 5 ). However, there was a considerable variation among soils of the districts in terms of available P (Table 5). This may be ascribed to the presence of higher concentrations of oxyhydroxides of $\mathrm{Al}$ and $\mathrm{Fe}$ which are responsible for fixation of $\mathrm{P}$ at the exchange sites for soils of Cheha district compared to soils of Dinsho. As per the rating established by EthioSIS (2014), the Mehlich-3 extractable P of the studied soils in Cheha fall in the very low range $\left(0-15 \mathrm{mg} \mathrm{kg}^{-1}\right)$, whereas soils of Dinsho exhibited low (15-30 $\mathrm{mg} \mathrm{kg}^{-1}$ ) Melich-3 P. Similarly, the rating proposed by Horneck et al. (2011) also indicated the predominantly low available $\mathrm{P}$ for 
Cheha $\left(<20 \mathrm{mg} \mathrm{kg}^{-1}\right.$ for Bray-1 P) and low to medium $\mathrm{P}$ for Dinsho soils ( $<20 \mathrm{mg} \mathrm{kg}^{-1}$ Bray 1 P $\left.20-40 \mathrm{mg} \mathrm{kg}^{-1}\right)$. The insufficiency may be due to acidic reaction in which free oxides of $\mathrm{Fe}$ and $\mathrm{Al}$ tend to fix $\mathrm{P}$ on the exchange sites. Reports of low available P in many parts of Ethiopian soils have been documented possibly due to the impacts of fixation, abundant loss by crop harvest and erosion (Asmare et al. 2015; Wolde et al. 2015).

The amounts of $\mathrm{P}$ extracted from studied soils decreased in the following order: Bray and Kurtz-1<Mehlich 3. The differences among the P extraction methods probably arose from the fact that plant available $\mathrm{P}$ in the soil is not from a prudent fraction but from a continuum of fractions. Thus extracting agents preferentially extract $P$ from different fractions depending on their reactions with soil components involved in $\mathrm{P}$ sorption. Furthermore, each extracting solution has a different ability to extract varying segment of soil $P$ because they were embattled at different pools of soil P (Zhang et al. 2004). Extractable P by the Mehlich-3, and Bray and Kurtz-1 in this study were correlated among themselves (Table 8). The correlation coefficient ( $r$ ) was appeared to be 0.96 indicating that any of these extractants could be used to estimate P extractability (available P) in soils. In spite of the strong positive correlations among these extractants, Mehlich-3 extraction method could be used as a substitute over the former conventional extraction method Bray and Kurtz-1 (1945) because of its capability to generate opportunities for optimization of laboratory management and cheaper procedure (Mesfin et al. 2014).

As per the ratings of Murphy (1968), the studied soils had a total $\mathrm{P}$ content that ranges from medium
(501-750 mg kg ${ }^{-1}$ ) to very high $\left(>1000 \mathrm{mg} \mathrm{kg}^{-1}\right.$ ). A gamut of results have been produced by several scholars on the total P contents of several soils of Ethiopia from various localities: $200-800 \mathrm{mg} \mathrm{kg}^{-1}$ (Eylachew 1987), 185 to $1981 \mathrm{mg} \mathrm{kg}^{-1}$ (Tekalign and Haque 1991), 226-1570 mg kg-1 (Duffera and Robarge 1996), 553$976 \mathrm{mg} \mathrm{kg}^{-1}$ (Achalu et al. 2012) and 685-1432 $\mathrm{mg} \mathrm{kg}^{-1}$ (Asmare et al. 2015). The result also indicates that the total P content of the studied soils was much higher than $200 \mathrm{mg} \mathrm{kg}^{-1}$ which was the value indicated by Olsen and Engelstad (1972) as the maximum total P value for highly weathered tropical soils. The total P content determined in this study was very far from a report made on soils from northwestern highlands of Ethiopian for which the total P content ranged from 6900 to $24,000 \mathrm{mg} \mathrm{kg}^{-1}$ with a mean value of $12,275 \mathrm{mg} \mathrm{kg}^{-1}$ (Birru et al. 2003). However, the normal range of total $\mathrm{P}$ in soils is 100 $3000 \mathrm{mg} \mathrm{kg}^{-1}$ (Frossar et al. 2000). Viewing the total P contents of some tropical soils, Asmare et al. (2015) observed that the total $\mathrm{P}$ contents of Ethiopian soils were not as poor as the other tropical soils. Surprisingly, despite the medium to high contents of total $P$, the available P contents of the studied soils were in low to very low range (Table 5).

\section{Inorganic and organic phosphorus fractions}

The amount, distribution and sum of various $\mathrm{P}$ fractions of the soils studied are presented in Table 6. The relative abundance of $\mathrm{P}$ forms was in the following order: Res- $\mathrm{P}>\mathrm{NaOH}-\mathrm{Po}>\mathrm{NaOH}-\mathrm{Pi}>\mathrm{HCl}-\mathrm{P}>(\mathrm{NaOH}-$ $\mathrm{Pi}) \mathrm{sn}>(\mathrm{NaOH}-\mathrm{Po}) \mathrm{sn}>\mathrm{NaHCO}_{3}-\mathrm{Po}>\mathrm{NaHCO}_{3}-$ $\mathrm{Pi}>\mathrm{NH}_{4} \mathrm{Cl}$ in soils from Cheha district, whereas

Table 6 Inorganic and organic $P$ fractions and their distribution

\begin{tabular}{|c|c|c|c|c|c|c|c|c|c|c|}
\hline Sites & $\mathrm{NH}_{4} \mathrm{Cl}-\mathrm{Pi}$ & $\mathrm{NaHCO}_{3}-\mathrm{Pi}$ & $\mathrm{NaHCO}_{3}-\mathrm{Po}$ & $\begin{array}{l}\mathrm{NaOH}-\mathrm{Pi} \\
\left(\mathrm{mg} \mathrm{kg}^{-1}\right)\end{array}$ & $\mathrm{NaOH}-\mathrm{Po}$ & (NaOH-Pi)sn & (NaOH-Po)sn & $\mathrm{HCl}-\mathrm{P}$ & Resl-P & Sum $\sum P$ \\
\hline SC1 & 1.93 & 2.43 & 2.74 & 135.31 & 160.41 & 31.74 & 35.31 & 71.32 & 164.15 & 606.34 \\
\hline SC2 & 3.23 & 3.72 & 3.91 & 139.71 & 196.87 & 40.93 & 85.17 & 86.89 & 216.25 & 776.68 \\
\hline SC3 & 1.69 & 2.45 & 2.78 & 130.45 & 167.59 & 33.9 & 36.28 & 77.01 & 185.18 & 637.33 \\
\hline SC4 & 2.53 & 2.06 & 3.63 & 129.66 & 180.82 & 37.76 & 76.68 & 77.88 & 187.30 & 698.32 \\
\hline SC5 & 2.32 & 2.59 & 2.97 & 124.13 & 168.69 & 36.33 & 72.85 & 75.57 & 177.55 & 663.00 \\
\hline SC6 & 2.59 & 2.72 & 4.04 & 138.82 & 190.94 & 44.24 & 79.32 & 83.55 & 213.41 & 759.63 \\
\hline SC7 & 2.06 & 2.11 & 3.85 & 131.76 & 182.48 & 38.10 & 77.6 & 77.95 & 190.94 & 706.85 \\
\hline SD1 & 5.90 & 7.61 & 9.35 & 89.65 & 154.49 & 28.28 & 72.29 & 379.32 & 317.24 & 1064.13 \\
\hline SD2 & 3.90 & 5.12 & 5.63 & 82.76 & 144.32 & 23.42 & 70.50 & 354.86 & 301.16 & 992.67 \\
\hline SD3 & 7.40 & 7.75 & 8.95 & 97.37 & 168.11 & 30.40 & 77.76 & 407.26 & 340.73 & 1145.73 \\
\hline SD4 & 5.90 & 6.51 & 6.53 & 86.63 & 147.56 & 27.01 & 69.03 & 362.64 & 303.60 & 1015.41 \\
\hline SD5 & 6.90 & 7.14 & 7.97 & 96.12 & 161.64 & 31.22 & 72.71 & 391.69 & 324.87 & 1100.26 \\
\hline Mean & 3.86 & 4.35 & 5.19 & 115.20 & 168.66 & 33.61 & 68.79 & 203.83 & 243.53 & 847.20 \\
\hline
\end{tabular}

$\mathrm{NH}_{4} \mathrm{Cl}-\mathrm{P}$ ammonium extractable $\mathrm{P}, \mathrm{NaHCO}_{3}$-Pi sodium bicarbonate extractable inorganic $\mathrm{P}, \mathrm{NaHCO}_{3}$ - $\mathrm{PO}$ sodium bicarbonate extractable organic $\mathrm{P}, \mathrm{NaOH}-\mathrm{Pi}$ sodium hydroxide extractable inorganic $\mathrm{P}, \mathrm{NaOH}$-po sodium hydroxide extractable organic $\mathrm{P},(\mathrm{NaOH}$ - $\mathrm{Pi})$ sn sonicated sodium hydroxide extractable inorganic $\mathrm{P}$, $(\mathrm{NaOH}$-po)sn sonicated sodium hydroxide extractable organic $\mathrm{P}, \mathrm{HCl}-\mathrm{P}$ hydrochloric acid extractable $\mathrm{P}, \sum \mathrm{P}$ sum of $\mathrm{P}$ fractions 
HCl- $\mathrm{P}>$ Res- $\mathrm{P}>\mathrm{NaOH}-\mathrm{Po}>\mathrm{NaOH}-\mathrm{Pi}>(\mathrm{NaOH}-\mathrm{Po})$ sn $>(\mathrm{NaOH}-\mathrm{Pi})$ sn $>\mathrm{NaHCO}_{3}-\mathrm{Po}>\mathrm{NaHCO}_{3}-\mathrm{Pi}>\mathrm{NH}_{4} \mathrm{Cl}$ was the order for soils of Dinsho district. The labile $\mathrm{P}(\mathrm{Pi}$ in $\mathrm{NH}_{4} \mathrm{Cl}+\mathrm{Pi}$ and $\mathrm{Po}$ in $\mathrm{NaHCO}_{3}$ ) varied between 1.1 and $2.2 \%$, the moderately labile $\mathrm{P}(\mathrm{Pi}+\mathrm{Po}$ in $\mathrm{NaOH})$, varied between 22.9 and $48.8 \%$, the occluded $\mathrm{P}(\mathrm{Pi}+\mathrm{Po}$ in Sonicate $+\mathrm{NaOH}$ ) varied between 9.4 and $16.5 \%$, the $\mathrm{P}$ associated to $\mathrm{Ca}(\mathrm{HCl}-\mathrm{Pi})$ varied between 11.0 and $35.8 \%$ and the residual-P varied between 26.8 and $30.3 \%$. It could be concluded that soils of Cheha district are dominated by Res-P (occluded Pi associated with the remaining inorganic minerals and non extractable Po) followed by $\mathrm{NaOH}$ extractable $\mathrm{P}(\mathrm{NaOH}-\mathrm{Po}$ and $\mathrm{NaOH}-\mathrm{Pi})$. On the other hand, it was $\mathrm{HCl}-\mathrm{P}$ that dominates $\mathrm{P}$ fractions in soils of Dinsho district indicating (Ca)-Pi mineral were very prominent in these soils. Similar work has been conducted by Duffera and Robarge (1996) who characterized organic and inorganic $\mathrm{P}$ in the highland Plateau Alfisols of Ethiopia and reported that the relative abundance in cultivated farmers' fields was in the ensuing order: Residual $\mathrm{P}>\mathrm{NaOH}-\mathrm{Po}>\mathrm{NaOH}-\mathrm{Pi}>$ Sonic- $\mathrm{Po}>\mathrm{NaHCO}_{3}-$ $\mathrm{Po}>$ Resin- $\mathrm{P}=$ Sonic $-\mathrm{Pi}>\mathrm{NaHCO}_{3}-\mathrm{Pi}=\mathrm{HCl}-\mathrm{P}$.

In the studied soils considerable proportions of $\mathrm{P}$ $\left(\mathrm{NaHCO}_{3}-\mathrm{P}_{\mathrm{o}}\right)$ that may be easily mineralized were noticed and ranged from 36.00 to $48.00 \%$ indicating the significance of organically bound $\mathrm{P}$ as a source of labile, plant available P (Duffera and Robarge 1996). In this regard Cross and Schlesinger (1995) suggested that the bicarbonate Po as a percent of the total labile forms of $\mathrm{P}$ (resin $\mathrm{Pi}$, bicarbonate $\mathrm{Pi}$, and bicarbonate Po) represents a minimum index of the proportion of $\mathrm{P}$ that may be easily mineralized through biological processes. In clayey soils of Dinsho district, the sum of $\mathrm{NH}_{4} \mathrm{Cl}-\mathrm{P}, \mathrm{NaHCO}_{3}-\mathrm{P}$ and $\mathrm{NaOH}-\mathrm{P}$ was smaller than oxalate-P, indicating that the oxalate method extracted some residual $\mathrm{P}$ that contained insoluble inorganic $\mathrm{P}$ associated with $\mathrm{Ca}$ minerals and a highly resistant pool of inorganic occluded $\mathrm{P}$ and organic P (Table 6).

The result of the present study also revealed that the studied soils from Cheha district were dominated by moderately labile $\mathrm{P}$ fractions, accounting for $43.3-48.8 \%$ of the total $\mathrm{P}$, whereas $\mathrm{NH}_{4} \mathrm{Cl}-\mathrm{P}$ was the lowest in concentration, $0.3-0.4 \%$ of the total P. On the other hand, the studied soils of Dinsho district were dominated by $\mathrm{HCl}$ $\mathrm{P}, 35.6-35.8 \%$ of the total $\mathrm{P}$, while $\mathrm{NH}_{4} \mathrm{Cl}-\mathrm{P}$ was the least in proportion (0.4-0.7\%). Residual-P, which accounted for about 29.5-30.3\% (Dinsho) and 26.8-28.1\% (Cheha) of the total $\mathrm{P}$, was the second higher fraction followed by moderately labile-P (22.9-23.4\%) and occluded-P (11.0$16.5 \%)$ fractions, respectively (Table 6). The relatively higher abundance of $\mathrm{Al}$ and $\mathrm{Fe}$ bound $\mathrm{P}$ could be associated with the presence of variable $\mathrm{Al}$ and $\mathrm{Fe}$ contents in soils at various stages of relative development and their reaction with soil P (Kiflu et al. 2017). On the other hand, the $\mathrm{P}$ associated to $\mathrm{Ca}(\mathrm{HCl}-\mathrm{Pi})$ varied between 11.0 and $35.8 \%$, which could be attributed to the difference in $\mathrm{Ca}$ content of the studied soils and the residual-P varied between 26.8 and $30.3 \%$ (Table 7).

A noticeable variability in proportion of $\mathrm{P}$ fractions in the order of their relative abundance in the studied soils of the two districts was observed. The management practices being used by farmers and the extent of weathering of soils might have contributed for the variations in concentrations and distributions of different forms of $\mathrm{P}$. As an illustration, $\mathrm{NaOH}$ extractable $\mathrm{P}$ in soils of Cheha district, which accounted for about

Table 7 Oxalate and dithionite citrate bicarbonate extractable Al, Fe and P

\begin{tabular}{|c|c|c|c|c|c|c|c|c|c|c|}
\hline Sites & $\begin{array}{l}\mathrm{Al}_{\mathrm{ox}} \\
\text { (mmol }\end{array}$ & $\mathrm{Fe}_{\text {ox }}$ & $P_{\text {ox }}$ & PSC & $\begin{array}{l}\mathrm{P}_{\text {ox }}^{\mathbf{a}} \\
\text { DPS (\% }\end{array}$ & $A I_{d}$ & $\begin{array}{l}\mathrm{Fe}_{\mathrm{d}} \\
\text { (mmol }\end{array}$ & $A I_{d}-A I_{o x}$ & $\mathrm{Fe}_{\mathrm{ox}} / \mathrm{Fe}_{\mathrm{d}}$ & $\begin{array}{l}\text { Scaling } \\
\text { factor (a) }\end{array}$ \\
\hline SC1 & 152.37 & 97.70 & 5.51 & 133.54 & 4.13 & 173.33 & 633.66 & 20.6 & 0.24 & 0.62 \\
\hline SC2 & 139.07 & 78.54 & 6.17 & 116.20 & 5.31 & 151.85 & 478.04 & 12.78 & 0.29 & 0.62 \\
\hline SC3 & 145.96 & 88.18 & 5.82 & 125.03 & 4.65 & 164.07 & 551.61 & 18.11 & 0.27 & 0.57 \\
\hline SC4 & 130.07 & 79.96 & 6.07 & 112.16 & 5.41 & 144.07 & 456.25 & 14.00 & 0.29 & 0.59 \\
\hline SC5 & 126.37 & 77.46 & 7.07 & 108.85 & 6.49 & 149.26 & 491.61 & 22.89 & 0.26 & 0.61 \\
\hline SC6 & 131.85 & 76.39 & 7.32 & 111.20 & 6.58 & 161.11 & 476.61 & 29.26 & 0.28 & 0.62 \\
\hline SC7 & 134.37 & 81.75 & 6.45 & 115.41 & 5.59 & 150.74 & 498.75 & 16.37 & 0.27 & 0.56 \\
\hline SD1 & 90.00 & 66.21 & 9.74 & 83.42 & 11.68 & 119.26 & 313.93 & 29.26 & 0.29 & 0.42 \\
\hline SD2 & 91.85 & 82.29 & 8.26 & 92.99 & 8.88 & 112.19 & 355.54 & 20.33 & 0.26 & 0.45 \\
\hline SD3 & 71.89 & 51.75 & 12.29 & 66.02 & 18.62 & 134.07 & 281.07 & 62.19 & 0.26 & 0.45 \\
\hline SD4 & 90.37 & 59.43 & 8.39 & 79.99 & 10.49 & 128.52 & 307.14 & 38.15 & 0.29 & 0.44 \\
\hline SD5 & 78.15 & 63.36 & 10.35 & 75.56 & 13.69 & 124.07 & 291.43 & 45.93 & 0.27 & 0.44 \\
\hline Mean & 115.19 & 75.25 & 7.79 & 101.70 & 8.46 & 142.71 & 427.97 & 27.52 & 0.27 & 0.53 \\
\hline
\end{tabular}

$A l_{o x}$ oxalate extractable $\mathrm{Al}, F e_{o x}$ oxalate extractable $P_{o x}$ oxlate extractable $\mathrm{P}, P S C$ phosphorous sorption capacity, DPS $\mathrm{P}$ saturation with respect to Pox, $A l_{d}$ dithionite extractable $\mathrm{Al}, \mathrm{Fe}_{d}$ dithionite extractable $\mathrm{Fe}$ 
$59.9 \%$ of the total P, was in higher proportion compared to the $32.6 \%$ in soils of Dinsho district. Likewise, $\mathrm{HCl}$ extractable $\mathrm{P}$, which was $11.4 \%$ of the total $\mathrm{P}$ in Cheha soils, was much lower than the $35.7 \%$ in Dinsho soils. This could be due to the dominance of free $\mathrm{Fe}$ and $\mathrm{Al}$ oxides and higher extent of weathering in soils of Cheha district compared to Dinsho soils as indicated in Table 7.

The dependence of different forms of $\mathrm{P}$ upon the physical and chemical properties of the soil was tested using correlation analysis (Table 9). Thus, $\mathrm{NH}_{4} \mathrm{Cl}-\mathrm{P}_{\mathrm{i}}$, $\mathrm{NaHCO}_{3}$-Po and $\mathrm{NaHCO}_{3}$-Pi were positively and significantly correlated with $\mathrm{pH}, \mathrm{CEC}, \mathrm{OC}$ and available $\mathrm{P}$ but negatively and significantly correlated with exAc and exAl. The other forms of $\mathrm{P}$, such as $\mathrm{NaOH}-\mathrm{Po}$ and $\mathrm{NaOH}-\mathrm{Pi}$, were negatively and significantly correlated with $\mathrm{pH}, \mathrm{CEC}, \mathrm{OC}$, and available $\mathrm{P}$ (Mehlich $3 \mathrm{P}$ ). Furthermore, the present study revealed that $\mathrm{NH}_{4} \mathrm{Cl}-\mathrm{P}_{\mathrm{i}}$ $(\mathrm{r}=-0.87, \mathrm{P} \leq 0.01), \mathrm{NaHCO}_{3}-\mathrm{Pi}(\mathrm{r}=-0.85, \mathrm{P} \leq 0.01)$, $\mathrm{NaHCO}_{3}-\mathrm{Po}(\mathrm{r}=-0.89, \mathrm{P} \leq 0.01)$ and $\mathrm{HCl}-\mathrm{P}(\mathrm{r}=-0.82$, $\mathrm{P} \leq 0.01$ ) were negatively and significantly correlated with clay content. It may be inferred that the concentrations and distributions of these $\mathrm{P}$ fractions are smaller in soils where there is high clay content. The outcome of the present study was found to be in agreement with the correlation result obtained by Duffera and Robarge (1996) whose result exhibited negative correlation between clay content and the readily available $\mathrm{P}$ fractions, the bicarbonate $\mathrm{Pi}$ and $\mathrm{HCl}$ extractable $\mathrm{P}$ for highland soils from Ethiopia.

The $\mathrm{P}$ contents in terms of the sum of $\mathrm{P}$ fractions in the surface soil samples ranged from $606.3 \mathrm{mg} \mathrm{kg}^{-1}$ in the SC1 soil collected from Cheha district to $1145.7 \mathrm{mg} \mathrm{kg}^{-1}$ in the SD3 soil collected from the Dinsho district indicating a closer similarity between total $\mathrm{P}$ determined through direct digestion technique and summation of the $P$ fractions. In general, the sum of the various $P$ fractions was within $4 \%$ of the total P content determined by the Olsen and Sommers (1982) approach, indicating that the fractionation procedure does account for almost all of the P present in the soils.

\section{Oxalate and dithionite citrate bicarbonate extractable Al, Fe and $P$}

The distribution of oxalate and dithionite citrate bicarbonate extractable $\mathrm{Al}$ and $\mathrm{Fe}$ oxides values of the studied soils are presented in Table 7. Accordingly, considerable variations among the studied soils with respect to $\mathrm{DCB}$ and oxalate extractable $\mathrm{Al}$ and $\mathrm{Fe}$ were observed. The disparity in relative abundance of aluminum and iron oxides in studied soils, which are the most important phosphate adsorbents in weathered acidic soils, might have contributed to the variations observed in extractable $\mathrm{Al}$ and $\mathrm{Fe}$.
Substantial differences were observed between dithionite extractable $\mathrm{Fe}$ and $\mathrm{Al}$ in the soils. This might be due to the fact that the dithionite in the dithionite citrate bicarbonate procedure is a reducing agent and it might have reduced $\mathrm{Fe}^{3+}$ to $\mathrm{Fe}^{2+}$ and thereby increased the solubility of Fe. However, $\mathrm{Al}$ is not a redox sensitive element and hence treatment with reducing agents such as dithionite is not likely to cause much extraction of $\mathrm{Al}$.

The differences between $\mathrm{DCB}$-extractable $\mathrm{Fe}$ and $\mathrm{Al}$ oxides and oxalate-extractable $\mathrm{Fe}$ and $\mathrm{Al}$ oxides represent the amounts of extracted crystalline $\mathrm{Fe}$ (c-Fe) and $\mathrm{Al}(\mathrm{c}-\mathrm{Al})$ oxides. There was a large amount of $\mathrm{c}-\mathrm{Fe}$ (76.9-84.6\% of total $\mathrm{Fe}$ ). In contrast, c-Al content was low (8.4-46.4\% of total Al) (Table 7). The observed variation in the amount of crystalline $\mathrm{Fe}$ and $\mathrm{Al}$ might be ascribed to the amount of organic matter present in the soil. In agreement with the results of the existing study, Kang et al. (2009) reported that organic matter in soil inhibits $\mathrm{Al}$ oxides crystallization. The oxalate extractable $\mathrm{Al}$, and $\mathrm{Fe}$ values ranged from 1941.03 to $4113.99 \mathrm{mg} \mathrm{Al}$ $\mathrm{kg}^{-1}$ and from 2898 to $5471.2 \mathrm{mg} \mathrm{Fe} \mathrm{kg}^{-1}$ were comparable with acid soils of northwestern highlands of Ethiopia that contained 3528-5432 $\mathrm{mg} \mathrm{Fe} \mathrm{kg}^{-1} 3699-4779 \mathrm{mg}$ $\mathrm{Al} \mathrm{kg}^{-1}$ (Asmare et al. 2015). However, these extractable forms were higher than acidic soils of European countries that are characterized by an average of $1835.2 \mathrm{Fe}_{\mathrm{ox}} \mathrm{kg}^{-1}$ to $2349.8 \mathrm{mg} \mathrm{Al}_{\text {ox }} \mathrm{kg}^{-1}$ (Roberto and Giampietro 2005). The ratio of $\mathrm{Fe}_{\mathrm{ox}} / \mathrm{Fe}_{\mathrm{d}}$ has been taken as an indicator of the maturity or crystallinity of free Fe oxides in soils (Blume and Schwertmann 1969). The value of the $\mathrm{Fe}_{\mathrm{ox}} / \mathrm{Fe}_{\mathrm{d}}$ for the studied soils ranged from 0.24 to 0.29 . All the values of $\mathrm{Fe}_{\text {ox }} / \mathrm{Fe}_{\mathrm{d}}$ ratio for studied soil samples were $>0.1$, which indicates that poorly crystalline iron oxides are dominant in these soils (Fitzpatrick and Schwertmann 1982).

As it may also be seen in Table 7 the $\mathrm{P}_{\mathrm{ox}}$ of the studied soils was ranged from 5.51 to $12.89 \mathrm{mmol} \mathrm{kg}^{-1}$ and were higher than acidic soils of West African soils which held 0.35 to $3.42 \mathrm{mmol} \mathrm{P}_{\text {ox }} \mathrm{kg}^{-1}$ (Narteh and Sahrawat 1999). The observed difference in $P_{\text {ox }}$ of the soils might be attributed to the variation in their poorly crystalline $\mathrm{Fe}$ and $\mathrm{Al}$ which are the most reactive fractions of soil iron and aluminum oxides.

The correlation matrix (Tables 8 and 9), Table 9 indicates that readily available $\mathrm{P}$ fractions $\left(\mathrm{NH}_{4} \mathrm{Cl}\right.$, $\mathrm{NaHCO}_{3}-\mathrm{Pi}$ and $\mathrm{NaHCO}_{3}-\mathrm{Po}$ ) had a significantly negative relationship with $\mathrm{Fe}_{\mathrm{ox}}[(\mathrm{r}=-0.89, \mathrm{P} \leq 0.01), \mathrm{r}=-0.82$, $\mathrm{P} \leq 0.01, \mathrm{r}=-0.84, \mathrm{P} \leq 0.01)], \mathrm{Al}_{\text {ox }}[(\mathrm{r}=-0.94, \mathrm{P} \leq 0.01)$, $\mathrm{r}=-0.93, \mathrm{P} \leq 0.01, \mathrm{r}=-0.92, \mathrm{P} \leq 0.01)]$ respectively. This result indicates that soils with high concentrations of free oxyhydroxides of aluminum and iron are deprived of $\mathrm{NH}_{4} \mathrm{Cl}$ and $\mathrm{NaHCO}_{3}$ extractable P. The negative relationship among oxalate and dithionite extractable metal oxides and readily available fractions of $\mathrm{P}$ is in agreement 
Table 8 Correlation table for some soil properties

\begin{tabular}{|c|c|c|c|c|c|c|c|c|c|c|c|c|c|}
\hline & Clay & $\mathrm{pH}$ & exAc & exAl & OC & Mehl 3P & Bra P & $\mathrm{Fe}_{\text {ox }}$ & $A I_{o x}$ & $\mathrm{Fe}_{\mathrm{d}}$ & PSC & DPS & $P_{\text {ox }}$ \\
\hline $\mathrm{pH}$ & $-0.66^{*}$ & & & & & & & & & & & & \\
\hline exAc & 0.51 & $-0.90^{* *}$ & & & & & & & & & & & \\
\hline exAl & $0.65^{*}$ & $-0.72^{* *}$ & $0.79^{* *}$ & & & & & & & & & & \\
\hline LR & $0.81^{* *}$ & $-0.88^{* *}$ & $0.94^{* *}$ & $0.71^{* *}$ & & & & & & & & & \\
\hline OC & $0.83^{* *}$ & $0.88^{* *}$ & $-0.94^{* *}$ & $-0.79^{* *}$ & & & & & & & & & \\
\hline M $3 P$ & $-0.82^{* *}$ & $0.81^{* *}$ & $-0.86^{* *}$ & $-0.86^{* *}$ & $0.93^{* *}$ & & & & & & & & \\
\hline Bra P & $-0.80^{* *}$ & $0.81^{* *}$ & $-0.84^{* *}$ & -0.54 & $0.90^{* *}$ & $0.96^{* *}$ & & & & & & & \\
\hline $\mathrm{Fe}_{\mathrm{ox}}$ & $0.80^{* *}$ & $-0.79^{* *}$ & $0.81^{* *}$ & $0.81^{* *}$ & $-0.88^{* *}$ & $-0.85^{* *}$ & $-0.80^{* *}$ & & & & & & \\
\hline $\mathrm{Al}_{\mathrm{Ox}}$ & $0.83^{* *}$ & $-0.85^{* *}$ & $0.93^{* *}$ & $0.93^{* *}$ & $-0.97^{* *}$ & $-0.95^{* *}$ & $-0.94^{* *}$ & $0.86^{* *}$ & & & & & \\
\hline $\mathrm{F}_{\mathrm{ed}}$ & $0.99^{* *}$ & $-0.85^{* *}$ & $0.92^{* *}$ & $0.92^{* *}$ & $-0.96^{* *}$ & $-0.92^{* *}$ & $-0.90^{* *}$ & $0.90^{* *}$ & $0.97^{* *}$ & & & & \\
\hline PSC & $0.85^{* *}$ & $-0.86^{* *}$ & $0.92^{* *}$ & $0.92^{* *}$ & $-0.93^{* *}$ & $-0.95^{* *}$ & $-0.93^{* *}$ & $0.93^{* *}$ & $0.98^{* *}$ & $0.98^{* *}$ & & & \\
\hline DPS & $-0.88^{* *}$ & $0.73^{* *}$ & $0.81^{* *}$ & $-0.81^{* *}$ & $0.87^{* *}$ & $0.91 * *$ & $0.89 * *$ & $-0.89^{* *}$ & $-0.93^{* *}$ & $-0.87^{* *}$ & $-0.95^{* *}$ & & \\
\hline$P_{\text {ox }}$ & $-0.91^{* *}$ & $0.75^{* *}$ & $-0.82^{* *}$ & $-0.82^{* *}$ & $0.88^{* *}$ & $0.92^{* *}$ & $0.88^{* *}$ & $-0.88^{* *}$ & $-0.94^{* *}$ & $-0.88^{* *}$ & $-0.95^{* *}$ & $0.99 * *$ & \\
\hline CEC & $-0.67^{*}$ & $0.66^{*}$ & $-0.78^{* *}$ & $-0.78^{* *}$ & $0.84^{* *}$ & $0.87^{* *}$ & $0.77^{* *}$ & $-0.87^{* *}$ & $-0.83^{* *}$ & $-0.91^{* *}$ & $0.86^{* *}$ & $0.83^{* *}$ & $0.86^{* *}$ \\
\hline
\end{tabular}

$L R$ lime requirements, Meh/ $3 P$ Mehlich $3 P, B r a P$ Bray $1 \mathrm{P}$, Ols $P$ Olsen $P, L R$ lime requirement, exAl exchangeable Al, exAc exchangeable Acidity, OC organic carbon, Alox, Feox, and Pox oxalate extractable Al, Fe, and P, respectively, PSC phosphorous sorption capacity, DPS degree of P saturation, Fed citrate dithionite bicarbonate extractable Fe

*Significant at 0.05 and ${ }^{*}$ Significant at 0.01 probability levels, respectively

Table 9 Correlation table for fractions of $\mathrm{P}$ and some soil properties

\begin{tabular}{lccccccccccccc}
\hline & Clay & pH & exAc & exAl & OC & M 3P & $\mathrm{Fe}_{\mathbf{o x}}$ & $\mathbf{A l}_{\mathbf{o x}}$ & $\mathrm{Fe}_{\mathbf{d}}$ & PSC & DPS & P $_{\text {ox }}$ & CEC \\
\hline $\mathrm{NH}_{4} \mathrm{Cl}$ & $-0.87^{* *}$ & $0.82^{* *}$ & $-0.84^{* *}$ & $-0.84^{* *}$ & $0.89^{* *}$ & $0.94^{* *}$ & $-0.89^{* *}$ & $-0.94^{* *}$ & $-0.93^{* *}$ & $-0.96^{* *}$ & $0.94^{* *}$ & $0.94^{* *}$ & $0.82^{* *}$ \\
$\mathrm{NaHCO}_{3} \mathrm{pi}$ & $-0.85^{* *}$ & $0.81^{* *}$ & $-0.84^{* *}$ & $-0.84^{* *}$ & $0.88^{* *}$ & $0.96^{* *}$ & $-0.82^{* *}$ & $-0.93^{* *}$ & $-0.90^{* *}$ & $-0.92^{* *}$ & $0.91^{* *}$ & $0.91^{* *}$ & $0.80^{* *}$ \\
$\mathrm{NaHCO}_{3} \mathrm{PO}$ & $-0.89^{* *}$ & $0.78^{* *}$ & $-0.82^{* *}$ & $-0.82^{* *}$ & $0.85^{* *}$ & $0.95^{* *}$ & $-0.84^{* *}$ & $-0.92^{* *}$ & $-0.91^{* *}$ & $-0.92^{* *}$ & $0.92^{* *}$ & $0.93^{* *}$ & $0.89^{* *}$ \\
$\mathrm{NaOH} \mathrm{Pi}$ & 0.05 & $-0.81^{* *}$ & $0.89^{* *}$ & $0.89^{* *}$ & $-0.89^{* *}$ & $-0.89^{* *}$ & $0.64^{*}$ & $0.91^{* *}$ & $0.86^{* *}$ & $0.85^{* *}$ & $-0.74^{* *}$ & $-0.75^{* *}$ & $-0.72^{* *}$ \\
$\mathrm{NaOH} \mathrm{po}$ & -0.23 & -0.55 & 0.60 & 0.60 & -0.55 & -0.57 & 0.19 & 0.56 & 0.43 & 0.46 & -0.39 & -0.39 & -0.26 \\
$\mathrm{HCl} \mathrm{p}$ & $-0.82^{* *}$ & $0.81^{* *}$ & $-0.87^{* *}$ & $-0.87^{* *}$ & $0.92^{* *}$ & $0.97^{* *}$ & $-0.77^{* *}$ & $-0.96^{* *}$ & $-0.92^{* *}$ & $-0.93^{* *}$ & $0.88^{* *}$ & $0.89^{* *}$ & $0.81^{* *}$ \\
\hline
\end{tabular}

$L R$ lime requirements, Mehl $3 P$ Mehlich $3 P, B r a P$ Bray $1 \mathrm{P}, \mathrm{Ols} P$ Olsen $\mathrm{P}, L R$ lime requirement, exAl exchangeable Al, exAc exchangeable Acidity, $O C$ organic carbon, Alox, Feox, and Pox oxalate extractable Al, Fe, and P, respectively, PSC phosphorous sorption capacity, DPS degree of P saturation, Fed citrate dithionite bicarbonate extractable Fe

*Significant at 0.05 and ${ }^{* *}$ Significant at 0.01 probability levels, respectively

with the general assumption that the higher the value of free oxides of aluminum and iron, the stronger is the binding capacity of the soil for P. Consequently, the amount of $\mathrm{P}$ desorbed $\left(\mathrm{NH}_{4} \mathrm{Cl}-\mathrm{P}, \mathrm{NaHCO}_{3}-\mathrm{Pi}\right.$ and $\mathrm{NaHCO}_{3}$-Po) from the exchange sites with increasing levels of these free oxides could be decreased. The bicarbonate Po had strong negative $[(\mathrm{r}=-0.91, \mathrm{P} \leq 0.01)]$ correlation with $\mathrm{F}_{\text {ed }}$, as it had positive and significant association $[(\mathrm{r}=0.85, \mathrm{P} \leq 0.01)$ and $(\mathrm{r}=0.89, \mathrm{P} \leq 0.01)]$ with $\mathrm{OC}$ and $\mathrm{CEC}$, respectively. The correlation result of the present study is in agreement with what has been found by Tiessen et al. (1984) where organic P fractions were positively related to organic $\mathrm{C}$ despite the contrasting correlation result observed from bicarbonate Po and dithionite extractable $\mathrm{Fe}\left(\mathrm{Fe}_{\mathrm{d}}\right)$.

\section{Extent of phosphorus saturation}

As shown in Table 7, the degree of phosphorous saturation of the studied soils varied considerably ranging from 4.1 to 6.6 and $8.9-18.6 \%$ in Cheha and Dinsho districts respectively. The portions of soil exchangeable sites that were bound with $\mathrm{P}$ were greater for soils collected from different sampling sites of Dinsho as compared to soils collected from Cheha which had higher free metallic oxides. The extent at which the potential sites for $\mathrm{P}$ adsorption already occupied was designated by DPS (\%). Accordingly, the highest DPS (18.6\%) was recorded from Dinsho (SD3) and the lowest from Cheha (SC1) sampling site. Recent studies have shown that the degree of P saturation (DPS), as a function of the portion of the soil exchangeable sites that are bound with $\mathrm{P}$ (P sorbed) in relation to the number of 
sites available for $\mathrm{P}$ binding capacity (PBC), is a good indicator of the soil's potential to release $\mathrm{P}$ (Hooda et al. 2000). Therefore, the variation in DPS of the studied soils may be attributed to the disparity among these soils in terms of the number of sites available for binding P. In view of the cut off point for loss of $P$ due to runoff (Ige et al. 2005), all the samples showed DPS values lower than $20 \%$ indicating no risk of P loss from soil (Table 7). These low values might be attributed to the higher adsorption capacity of these soils.

Extractable $\mathrm{P}\left(\mathrm{NH}_{4} \mathrm{Cl}, \mathrm{NaHCO}_{3}-\mathrm{P}_{\mathrm{i}}\right.$ and $\left.\mathrm{NaHCO}_{3}-\mathrm{Po}\right)$ was positively correlated with DPS $(r=0.94, \mathrm{P} \leq 0.01$; $\mathrm{r}=0.91, \mathrm{P} \leq 0.01 ; \mathrm{r}=0.92, \mathrm{P} \leq 0.01$, respectively) and $\mathrm{P}_{\mathrm{ox}}$ $(\mathrm{r}=0.94, \mathrm{P} \leq 0.01 ; \mathrm{r}=0.91, \mathrm{P} \leq 0.01 ; \mathrm{r}=0.93, \mathrm{P} \leq 0.01$, respectively). This confirms that these soils are characterized by higher amounts of readily available P fractions, larger concentrations of oxalate extractable $\mathrm{P}\left(\mathrm{P}_{\mathrm{ox}}\right)$ and greater degree of phosphorous saturation.

Phosphorous determined from $\mathrm{NaOH}$ extracts $(\mathrm{NaOH}-$ $\mathrm{P}_{\mathrm{i}}$ ), which is thought to be $\mathrm{Fe}$ and $\mathrm{Al}$ bound $\mathrm{P}$, was positively correlated with $\mathrm{Fe}_{\mathrm{ox}}(\mathrm{r}=0.64, \mathrm{P} \leq 0.05)$ and $\mathrm{Al}_{\text {ox }}$ $(\mathrm{r}=0.91, \mathrm{P} \leq 0.01)$ despite the fact that it was negatively correlated with DPS $(r=-0.74, P \leq 0.01)$ and $P_{o x}$ $(\mathrm{r}=-0.75, \mathrm{P} \leq 0.01)$. The correlation result substantiate that in the case where higher concentrations of oxalate and dithionite extractable iron and aluminum oxides are observed, the amount of $\mathrm{P}$ determined from $\mathrm{NaOH}$ extracts is higher. The same result has been found by Adhami et al. (2013) who reported that oxalate extractable iron had positive association with $\mathrm{NaOH}$ extractable $\mathrm{P}$. This could be ascribed to the higher $\mathrm{Al}$ and $\mathrm{Fe}$ oxides on the exchange sites that might have resulted in lower $\mathrm{pH}$ at which the concentration of $\mathrm{NaOH}$ extractable $\mathrm{P}$ would become higher. Furthermore, $\mathrm{P}$ fraction determined from the $\mathrm{HCl}$ extract had a strong and negative association with $\mathrm{Fe}_{\mathrm{ox}}(\mathrm{r}=-0.77, \mathrm{P} \leq 0.01)$ and $\mathrm{Al}_{\mathrm{ox}}$ $(\mathrm{r}=-0.96, \mathrm{P} \leq 0.01)$ although it was positively correlated with DPS $(r=0.88, P \leq 0.01)$. Likewise, the correlation result proved that the higher the concentrations of extractable iron and aluminum in soil, the lower the concentrations of $\mathrm{P}$ determined from $\mathrm{HCl}$ extract. It has been reported by several studies that it is oxyhydroxydes of aluminum and iron in weathered acidic soils rather than Ca that supersede the active surface of soils on which $P$ is adsorbed (Agbenin 2003; Yan et al. 2013; Campos et al. 2016). Therefore, with increasing concentrations of these free oxides, the amount of $\mathrm{HCl}$ extractable $\mathrm{P}$ decreases. Besides, $\mathrm{NaOH}$ and $\mathrm{HCl}$ extractable $\mathrm{P}(\mathrm{NaOH}-\mathrm{Pi}$ and $\mathrm{HCl}-\mathrm{P}$ ) could be best predicted from $\mathrm{Al}_{\mathrm{ox}}$ and therefore put forth considerate information on the abundances and distributions of $\mathrm{NaOH}-\mathrm{Pi}$ and $\mathrm{HCl}-\mathrm{P}$ in the studied soils.

Mehlich 3 extractable $\mathrm{P}$ was negatively correlated with $\mathrm{Fe}_{\mathrm{ox}}, \mathrm{Al}_{\text {ox }}$ and $\mathrm{Fe}_{\mathrm{d}}(\mathrm{r}=-0.85, \mathrm{P} \leq 0.01 ; \mathrm{r}=-0.95$,
$\mathrm{P} \leq 0.01 ; \mathrm{r}=-0.92, \mathrm{P} \leq 0.01)$ respectively. It is evident that the higher the concentrations of free oxides of $\mathrm{Fe}$ and $\mathrm{Al}$, the lower the $\mathrm{pH}$, which triggers adsorption of $\mathrm{P}$ at the exchange sites; in effect Mehlich 3 extractable $\mathrm{P}$ (available P) would be decreased. Moreover, the Mehlich 3 extractable $\mathrm{P}$ could best be predicted from $\mathrm{Fe}_{\mathrm{ox}}, \mathrm{Al}_{\mathrm{ox}}$ and $F_{\text {ed }}$ and therefore put forth thought full information on the availability of $\mathrm{P}$ in the soils is still lacking.

\section{Conclusions}

The soils of the study area were strongly to very strongly acidic in reaction that triggers the fixation of $\mathrm{P}$ at the exchange sites in the presence of oxyhydroxides of Fe and Al. Despite the medium to high contents of total P, the Mehlich-3 extractable available $\mathrm{P}$ contents of the studied soils is in the low to very low range indicating P deficiency in the study area. Among the different fractions of P, $\mathrm{HC} 1$ extractable $\mathrm{P}$ fraction dominates the soils $\mathrm{P}$ pool for soils of Dinsho district, whereas soils' $P$ pool of Cheha district was dominated by res-P. The sum of the labile $\mathrm{P}$ fractions $\left(\mathrm{NH}_{4} \mathrm{Cl}-\mathrm{Pi}, \mathrm{NaHCO}_{3}-\mathrm{Pi}\right.$, and $\left.\mathrm{NaHCO}_{3}-\mathrm{Po}\right)$ constitutes less than $4 \%$ of total $\mathrm{P}$ in soils from both districts reflecting very low reserves of crystalline $\mathrm{Fe}$ and Al-P. The sum of P fractions, which ranged from 606.3 to $1145.7 \mathrm{mg} \mathrm{kg}^{-1}$, is almost equivalent to the total $\mathrm{P}$ determined through fusion method and reveals that the Hedley fractionation procedure could be used for determination of total $\mathrm{P}$. The high content of $\mathrm{Al}$ and $\mathrm{Fe}$ oxides and hydroxides present in the soil might be responsible for the strong fixation of the native $\mathrm{P}$ as well as the applied P. Given the presence of considerable amount of total P, low P availability and high soil acidity in the study areas further research has to be done on adsorption characteristics to determine the $P$ requirements of the soils for better P management.

\section{Authors' contributions}

BA: collected, analyzed, interpreted the data and made the final write up which was part of his Doctoral thesis in Soil Science at Haramaya University, Ethiopia. AMT, KK and AM, as co-authors. All authors read and approved the final manuscript.

\section{Author details \\ ${ }^{1}$ Department of Chemistry, School of Natural Sciences, Madda Walabu University, Bale-Robe, Ethiopia. ${ }^{2}$ Department of Chemistry, College of Natural and Computational Sciences, Haramaya University, Dire Dawa, Ethiopia. \\ ${ }^{3}$ School of Natural Resources Management and Environmental Sciences, Haramaya University, Dire Dawa, Ethiopia. ${ }^{4}$ Department of Plant Science, Col- lege of Agriculture and Natural Resource Sciences, Debre Berhan University, Debre Birhan, Ethiopia.}

\section{Acknowledgements}

The project was funded by SIDA (Swedish International Development Cooperation Agency) and Madawelabu University Thus, we would like to thank these institutions. We would also like to thank the anonymous reviewers who contributed significantly to the improvement of the article. 


\section{Competing interests}

The authors declare that they have no competing interests.

\section{Availability of data and materials}

Not applicable.

\section{Consent for publication}

Not applicable.

Ethics approval and consent to participate

Not applicable.

\section{Funding}

Ministry of education and SIDA provided fund for carrying out this study.

\section{Publisher's Note}

Springer Nature remains neutral with regard to jurisdictional claims in published maps and institutional affiliations.

Received: 19 February 2018 Accepted: 18 June 2018

Published online: 27 June 2018

\section{References}

Abayneh E, Ashenafi A (2006) Soils of Sinnana Agricultural Research Center. National Soil Research Center. Soil Survey and Land Evaluation Section, Addis Ababa

Abera Y, Belachew T (2011) Effects of land use on soil carbon and nitrogen in soils of Bale, Southeastern Ethiopia. Trop Subtrop Agroecosyst 14:229-235

Achalu C (2014) Assessment of the severity of acid saturations on soils collected from cultivated lands of east Wollega Zone, Ethiopia. Sci Technol Arts Res J 3(4):42-48

Achalu C, Heluf G, Kibebew K, Abi T (2012) Response of barely to liming of acid soils collected from different land use systems on Western Oromia, Ethiopia. J Biodivers Environ Sci 2:1-13

Achalu C, Martti E, Kari Y (2014) Sequential fractionation patterns of soil phos phorus collected from different land use systems of Dire Inchine District, West Shawa Zone, Ethiopia. Am Eur J Sci Res 9(3):51-57

Adhami E, Owliaie HR, Molavi R, Rezaei RM, Esfandbod M (2013) Effects of soil properties on phosphorous fractions in subtropical soils of Iran. J Soil Sci Plant Nutr 13(1):11-21

Agbenin JO (2003) Extractable iron and aluminum effects on phosphate sorption in a savanna alfisol. Soil Sci Soc Am J 67:589-595

Al Baquy MA, Jiu YL, Chen YX, Khalid M, Ren KX (2017) Determination of critical $\mathrm{pH}$ and $\mathrm{Al}$ concentration of acidic Ultisols for wheat and canola crops. Solid Earth 8: 149-159. http://www.solid-earth.net/8/149/2017/ https:// doi.org/10.5194/se-8-149-2017

Alemu L, Tekalign M, Wassie H, Hailu S (2016) Assessment and mapping of status and spatial distribution of soil macronutrients in Kambata Tembaro Zone, Southern Ethiopia. Adv Plants Agric Res 4(4):00144. https://doi. org/10.15406/apar.2016.04.00144

Asmare M, Heluf G, Markku YH, Birru Y (2015) Phosphorus status, inorganic phosphorus forms, and other physicochemical properties of acid soils of Farta District, Northwestern Highlands of Ethiopia. Hindawi Publish Corp Appl Environ Soil Sci. https://doi.org/10.1155/2015/748390

Aubertin GM, Kardos LT (1965) Root growth through porous media under controlled conditions. Soil Sci Am Proc 29:290-293

Bache BW, Williams EG (1971) A phosphate sorption index for soils. J Soil Sci 22:289-301

Barber SA (1984) Liming materials and practices. In: Adams F (ed) Soil acidity and liming. American Society of Agronomy Inc, Madison, pp 171-209

Birru Y, Heluf G, Gupta VP (2003) Sorption characteristics of soils of the northwestern highlands of Ethiopia. Ethiop J Nat Resour 5:1-16

Blume HP, Schwertmann U (1969) Genetic evaluation of profile distribution of aluminum, iron, and manganese oxides. Soil Sci Soc Am J 33(3):438-444

Börling K, Otabbong E, Barberis E (2001) Phosphorus sorption in relation to soil properties in some cultivated Swedish soils. Nutr Cycl Agroecosyst 59:39-46
Bray RH, Kurtz LT (1945) Determination of total, organic, and available forms of phosphorus in soils. Soil Sci 59:39-45

Bremner JM (1965) Methods of soil analysis. Part 2. American Society of Agronomy, Madison American Society of Agronomy, pp 1149-1178

Buresh RJ, Smithson P, Hellums DT (1997) Building soil phosphorus capital in Africa. In: Buresh RJ, Sanchez PA, Calhoum F (eds) Replenishing Soil Fertility in Africa. SSSA Special Publication No. 51. Soil Science Society of America, Madison, pp 111-149

Campos MD, Antonangelo JA, Alleoni LRF (2016) Phosphorus sorption index in humid tropical soils. Soil Tillage Res 156:110-118

Chen GC, He ZL, Huang CY (2000) Microbial biomass phosphorus and its significance in predicting phosphorus availability in red soils. Commun Soil Sci Plant Anal 31:655-667

Cross AF, Schlesinger WH (1995) A literature review and evaluation of the Hedley fractionation: applications to the biogeochemical cycle of soil phosphorus in natural ecosystems. Geoderma 64:197-214

Day PR (1965) Hydrometer method of particle size analysis. In: Black CA (ed) Methods of Soil Analysis. Agronomy Part I, No. 9. American Society of Agronomy, Madison, pp 562-563

De Kimpe CR, Laverdiere MR, Martel YA (1979) Surface area and exchange capacity of clay in relation to mineralogical composition of gleysolic soils. Can Soil Sci 59:341-347

Duffera M, Robarge WP (1996) Characterization of organic and inorganic phosphorus in the highland plateau soils of Ethiopia. Commun Soil Sci Plant Anal 27(15):2799-2814

EIAR (Ethiopian Institute of Agricultural Research) (2011) Coordination of national agricultural research system, Ethiopia. English and Amharic Version, Addis Ababa

EthioSIS (Ethiopian Soil Information System) (2014) Soil fertility status and fertility recommendation atlas for Tigray regional state, Ethiopia, July 2014. EthioSIS, Addis Ababa

Eylachew Z (1987) Study on the phosphorous status of different soil types of Charcher Highlands, South Eastern Ethiopia (Ph.D. dissertation). University of Jestus Liebig, Giessen

FAO (Food and Agriculture Organization) (1984) Provisional soil map of Ethiopia. Land Use Planning Project, Addis Ababa

FAO (Food and Agriculture Organization) (2006) Plant nutrition for food security: a guide for integrated nutrient management, fertilizer and plant nutrition bulletin 16. FAO, Rome

Fisseha H, Heluf G, Kibebew K, Birru Y (2014) Study of phosphorus adsorption and its relationship with soiproperties, analyzed with Langmuir and Freundlich models. Agric For Fisheries 3(1):40-51. https://doi.org/10.11648 /j.aff.20140301.18

Fitzpatrick RW, Schwertmann U (1982) Al-sabstitution goethite an indicator of pedogenic and other weathering environments in South Africa. Geoderma 27:335-347. https://doi.org/10.1016/0016-7061(82)90022-2

Frossar E, Condron LM, Oberson A, Sinaj S, Fardeau JC (2000) Processes governing phosphorous availability in temperate soils. J Environ Qual 29:15-23

GarcõÂa G, HernaÂndez T (1996) Organic matter in bare soils of the Mediterranean region with a semi-arid climate. Arid Soil Res Rehabil 10:31-41

Getachew F, Heluf G (2007) Characterization and fertility status of the soils of Ayehu Research Substation, northwestern highlands of Ethiopia. East Afr J Sci 1(2):160-169

Gupta PK (2004) Soil, plant, water and fertilizer analysis. AGROBIOS Publisher, India

Hassink J, Bouwman LA, Zwart KB, Bloem J, Brussard L (1993) Relationship between soil texture, physical protection of organic matter, soil biota, and C and N mineralization in grassland soils. Geoderma 57:105-128

Hazelton P, Murphy B (2007) Interpreting soil test results: what do all the numbers mean?, 2nd edn. CSIRO Publishing, Clayton

Hedley MJ, Stewart JWB, Chauhan BS (1982) Changes in inorganic and organic soil phosphorus fractions induced by cultivation practices and by laboratory incubations. Soil Sci Soc Am J 46:970-976

Herlihy M, McCarthy J (2006) Association of soil-test phosphorus with phosphorus fractions and adsorption characteristics. Nutr Cycl Agroecosyst 75:79. https://doi.org/10.1007/s10705-006-9013-2

Hooda PS, Rendell AR, Edwards AC, Withers PJA, Aitken MN, Trusedale VW (2000) Relating soil phosphorus indices to potential phosphorus release to water. J Environ Qual 29:1166-1171

Horneck DA, Sullivan DM, Owen JS, Hart JM (2011) Soil test interpretation guide EC1478. Oregon State University Extension Service, Corvallis 
Ige DV, Akinremi OO, Flaten DN (2005) Environmental index for estimating therisk of phosphorus loss in calcareous soils of Manitoba. J Environ Qual 34:1944-1951

Ikerra S (2004) Use of Minjingu phosphate rock combined with different organic inputs in improving phosphorus availability and maize yields on a Chromic Acrisol in Morogoro, Tanzania. PhD thesis, Sokoine University of Agriculture, Morogoro

Jamison VC, Weaver HH, Reed IF (1950) A hammer-driven soil core sampler. Soil Sci 69:487-496

Jiang X, Bol R, Willbold S, Vereecken H, Klumpp E (2015) Speciation and distribution of $\mathrm{P}$ associated with Fe and $\mathrm{Al}$ oxides in aggregate-sized fraction of an arable soil. Biogeosciences 12:6443-6452. https://doi.org/10.5194/ bg-12-6443-2015

Jones JB (2003) Agronomic handbook: management of crops, soils, and their fertility. Crcpress LLC, Boca raton

Kang JH, Hesterberg D, Osmond DL (2009) Soil organic matter effects on phosphorus Sorption: a path analysis. Soil Sci Soc Am J 73:360-366

Kiflu A, Sheleme B, Schoenau J (2017) Fractionation and availability of phosphorus in acid soils of Hagereselam, Southern Ethiopia under different rates of lime Chem. Biol Technol Agric 4:21. https://doi.org/10.1186/s4053 8-017-0105-9

Kissel DE, Vendrell PF Isaac B (2004) Third quarter NAPT report, 2004. http:// www.naptprogram.org/files/napt/publications/methodpapers/2004s alt-concentration-and-measurement-of-soil-ph.pdf

Lavkulich LM (1981) Methods manual, pedology laboratory. Department of Soil Science, University of British Columbia, Vancouver, British Columbia

Loide V (2004) About the effect of the contents and ratios of soil's available calcium, potassium and magnesium in liming of acid soils. Agron Res 2(1):71-82

Maguire RO, Foy RH, Bailey JS, Sims JT (2001) Estimation of the phosphorus sorption capacity of acidic soils in Ireland. Eur J Soil Sci 52:479-487

McKeague JA, Day JH (1966) Dithionite and oxalate extractable Fe and Al as acids in differentiating various classes of soils. Can J Soil Sci 46:13-22

Mehlich A (1984) Mehlich-III soil test extractant: a modification of Mehlich 2. Commun Soil Sci Plant Anal 15:1409-1416

Mehra OP, Jackson ML (1960) Iron oxide removal from soils and clays by a dthionite-citrate system buffered with sodium bicarbonate. Clays Clay Miner 7:317-327

Mesfin B, Abi T, Heluf G, Asmare M (2014) Relation between Universal Extractants and Soybeans (Glycine max L.) response to P and K application under greenhouse conditions. Am J Plant Nutr Fertil Technol 4(2):57-67

Mohhammed M, Kibebew K, Tekalign M (2016) Fertility mapping of some micronutrients in soils of Cheha District, Gurage Zone, Southern Ethiopia. Afr J Soil Sci 4(3):313-320

Murphy HF (1968) A report on fertility status and other data on some soils of Ethiopia. Experimental station bulletin, no. 44. College of Agriculture HSIU, Ethiopia.

Narteh LT, Sahrawat KL (1999) Oxalate and EDTA extractable soil phosphorous and iron in relation to P availability in lowland rice soils of West Africa. Ghana Jnl Agric Sci 32:189-198

Negassa W, Leinwebe P (2009) How does the Hedley sequential phosphorus fractionation reflect impacts of land use and management on soil phosphorus: a review. J Plant Nutr Soil Sci 172:305-325. https://doi. org/10.1002/jpln.200800223305

Newey A (2006) Litter carbon turnover with depth. Ph.D. thesis, Australian National University, Canberra

Okubay G, Heluf G, Tareke B (2015) Soil fertility characterization in vertisols of southern Tigray, Ethiopia. Adv Plants Agric Res 2(1):1-7

Olsen RA, Engelstad OP (1972) Soil phosphorus and sulfur. Soils of the humid tropics. Natural Academy of Sciences, Washington, DC, pp 88-101

Olsen SR, Sommers LE (1982) Phosphorus. In: Page AL et al (ed) Methods of soil analysis. Part 2. 2nd ed. Agron Monogr 9. ASA and SSSA, Madison, p. 403-430

Peinemann N, Nilda MA, Pablo Z, Maria BV (2000) Effect of clay minerals and organic matter on the cation exchange capacity of silt fractions. J Plant Nutr Soil Sci 163(1):47-52. https://doi.org/10.1002/ (sici)1522-2624(200002)163:1<47::.aid-jpln47>3.0.co;2-a

Rasmussen PE, Allmaras RR, Rohde RR, Roager NC (1980) Crop residue influences on soil carbon and nitrogen in a wheat-fallow system. Soil Sci Soc Am J 44:596-600
Roberto I, Giampietro D (2005) Evaluating phosphorus sorption capacity of acidic soilsby short-term and long-term equilibration procedures. Commun Soil Sci Plant Anal 35(15-16):2269-2282

Rowell DL (1994) Soil Sience: method and applications. Addison Wesley Longman, London

Saljnikov KE, Funakawa S, Akhmetov K, Kosaki T (2004) Soil organic matter status of Mollisols soil in North Kazakhstan: effects of summer fallow. Soil Biol Biochem 36:1373-1381

Saljnikov E, Hospodarenko H, Funakawa S, Kosaki T (2005) Effect of fertilization and manure application on nitrogen mineralization potentials in Ukraine. Zemljiste I Biljka 54(3):221-230

Saljnikov E, Cakmak D, Kostic L, Maksimovic S (2009) Labile fractions of soil organic carbon in Mollisols from different climatic regions. Agrochimica LIII:6

SAS (Statistical Analysis System) version 9.1 (2004) SAS Institute

Shiferaw B (2004) Soil phosphorous fractions influenced by different cropping system in andosols and nitisols in Kambata-Tenbaro and Wolaita Zones, SNNPRS, Ethiopia, M.S. Thesis, Alemaya University, Dire Dawa, Ethiopia

Shoemaker HE, McLean EO, Pratt PF (1961) Buffer methods of determining lime requirements of soils with appreciable amounts of extractable aluminum. Soil Sci Soc Am J 25(4):274-277

Tekalign M, Haque I (1991) Phosphorous status of some Ethiopian soils, II. Forms and distribution of inorganic phosphates and their relation to available phosphorus. Trop Agric 68(1):2-8

Teshome Y, Heluf G, Kibebew K, Sheleme B (2013) Impacts of land use on selected physicochemical properties of soils of Abobo Area, Western Ethiopia. Agric For Fisheries 2(5):177-183. https://doi.org/10.11648 /j.aff.20130205.11

Tiessen H, Stewart JWB, Cole CV (1984) Pathways of P transformations in soils of differing pedogenesis. Soil Sci Soc Am J 48:853-858

USDANRCS (2004) United States Department of Agriculture, Natural Resources Conservation Service Soil survey laboratory methods manual. Version No. 4.0. Soil Survey Investigations Report No. 42

Van der Zee SEATM, Nederlof MM, Van Riemsdijk WH, de Haan FAM (1988) Spatial variability of phosphate adsorption parameters. J Environ Qual 17:682-688

Van Reeuwijk LP (1992) Procedures for soil analysis (3rd Ed) International Soil Reference and Information Center (ISRIC), Wageningen, the Netherlands, p 34

Walkley A, Black IA (1934) An examination of the Degtjareff method for determining soil organic matter and a proposed modification of the chromic acid titration method. Soil Sci 37:29-38

Wolde Z, Wassie H, Dhyna S (2015) Phosphorus sorption characteristics and external phosphorus requirement of Bulle and Wonago Woreda, Southern Ethiopia. Adv Crop Sci Tech 23(2):89-99

Xiea G, Steinbergera Y (2001) Temporal patterns of C and N under shrub canopy in a loessial soil desert ecosystem. Soil Biol Biochem 33:1371-1379

Yan X, Wang D, Zhang H, Zhang G, Wei Z (2013) Organic amendments affect phosphorus sorption characteristics in a paddy soil. Agric Ecosyst Environ 175:47-53

YuGe Z, ZhuWen X, DeMing J, Yong J (2013) Soil exchangeable base cations along a chronosequence of Caragana microphylla plantation in a semiarid sandy land, China. J Arid Land 5(1):42-50

Zhang M, Wright R, Heaney D, Vanderwel D (2004) Comparison of different phosphorus extraction and determination methods using manured soils. Can J Soil Sci 84:469-475

Zhou Q, Gibson CE, Zhu Y (2001) Evaluation of phosphorus bioavailability in sediments of three contrasting lakes in China and the UK. Chemosphere 42:221-225 